\title{
Comparative moisture and heat sorption properties of fibre and shiv derived from hemp and flax
}

\author{
Yunhong Jiang $(\mathbb{D} \cdot$ Michael Lawrence $\cdot$ Atif Hussain • Martin Ansell • \\ Pete Walker
}

Received: 2 July 2018/Accepted: 19 November 2018/Published online: 23 November 2018

(C) The Author(s) 2018

\begin{abstract}
Unlike many mineral-based insulation materials bio-based lignocellulosic fibre and shiv offer a number of benefits including thermal and hygroscopic properties. The microstructure, porosity and chemical compositions of the plant cell walls play a major role in the moisture exchange process. In this paper, the effects of microstructure, chemical composition, porosity and pore size distribution of both fibre and shiv, from hemp and flax plants, on both moisture and heat sorption were studied for the first time. The physical and chemical characteristics of the fibre and shiv from hemp and flax were studied by using scanning electron microscopy, mercury intrusion porosimetry and Fourier transform infrared spectroscopy. Water moisture sorption and heat of sorption were studied using a dynamic vapour sorption apparatus and a simultaneous thermal analysis system, combined with a humidity generator and using a copper furnace. Results showed that both the fibre and shiv of hemp and flax adsorbed a similar amount of moisture at a given relative humidity, which was
\end{abstract}

dependent on the availability of hydroxyl groups for water in the cell wall. The macroscopic surface area and porosity of the specimen on a large scale had little influence on the availability of hydroxyl groups in the cell wall. The water molecules bound with cell wall molecules through hydrogen bonds over the full range of relative humidities, with a consistent hysteresis difference between the first sorption isotherm and subsequent sequential sorption cycles found in the hemp shiv specimens. For both hemp and flax, the isothermic hysteresis of the shiv was much higher than that of the fibre, which was shown to be dependent on the lignin content. The result of heat sorption indicated that some blocked sorption sites become available to water vapour molecules due to the change in molecular structure of the cell wall during the adsorption process. This study has improved understanding of the hemp and flax sorption behaviour and is important for optimal application of bio-based insulation materials for construction.

Y. Jiang $(\varangle) \cdot$ M. Lawrence · A. Hussain ·

M. Ansell · P. Walker

BRE Centre for Innovative Construction Materials,

Department of Architecture and Civil Engineering,

University of Bath, Bath BA2 7AY, UK

e-mail: y.jiang@bath.ac.uk;

yunhongjiang@yahoo.com 


\section{Graphical abstract}

A

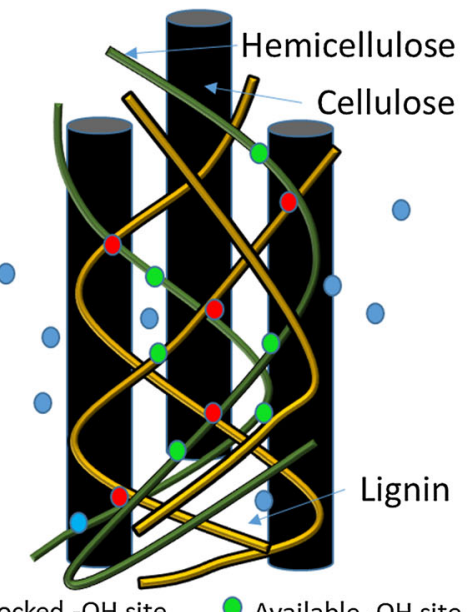

Blocked -OH site Available -OH site

O Water vapour molecule
B
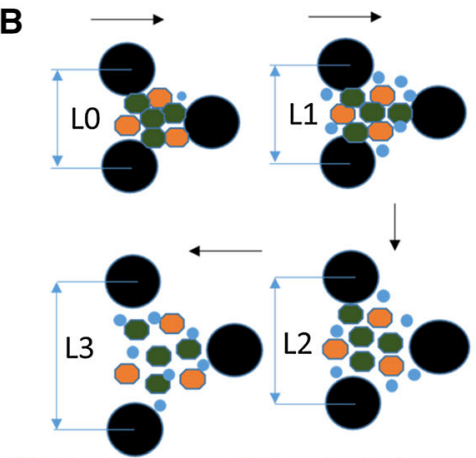

Lignin

Cellulose
- Hemicellulose

- Water vapour molecule

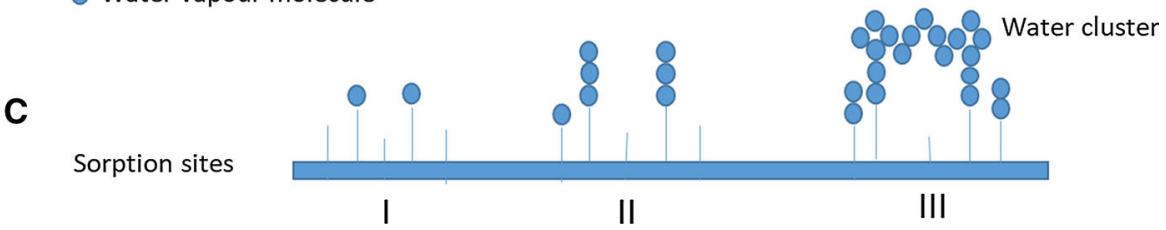

Keywords Microstructure - Porosity $\cdot$ Equilibrium moisture content $\cdot$ Sorption isotherm and sorption hysteresis

\section{Introduction}

Agro-industrial lignocellulosic materials such as hemp, flax, corn cob and straw (wheat, rice) are becoming more widely recognised for their excellent hygric and excellent insulating properties (Latif et al. 2014; Walker and Pavía 2014; Collet et al. 2017). Hemp and flax are versatile and fast-growing agricultural crops, which can be used as part of a crop rotation to condition soil. Acting as a carbon bank, hemp and flax lock in up to two tonnes of $\mathrm{CO}_{2}$ per tonne of fibre, making them a particularly sustainable choice for construction applications (Boutin et al. 2005). In the stem of natural plants, such as hemp and flax, a barklike layer containing fibres surrounds a woody core (Jiang et al. 2018). These components can be separated either by retting including chemical and microbial actions or mechanically, dividing the stem into bark fibres and woody stem (shiv) fractions. These materials have the potential to act as a building material to moderate humidity levels in an indoor environment due to their inherent hygroscopic properties (Latif et al. 2015; Laborel-Préneron et al. 2016; Hurtado et al. 2016; Bourdot et al. 2017). The components of fibres and shiv of flax and hemp include cellulose, hemicellulose, lignin, pectin, waxes and water soluble substances. The composition of selected fibres and shiv of flax and hemp are shown in Table 1. The major differences in chemical composition between the fibres and shiv were in the amounts of lignin. In addition, fibres had a higher content of cellulose compared with that of shiv.

Moisture levels in buildings have an influence on occupant comfort and fabric durability. Many building materials play an important role in influencing indoor air quality by adsorbing and desorbing moisture with their surroundings (Ferreira et al. 2017). Therefore, understanding hygroscopicity (the ability of a material to respond air moisture levels by either absorbing or releasing water vapour) of building materials is increasingly important. The hygroscopic behaviour of hemp and flax has been studied by a number of researchers (Nilsson et al. 2005; Hill et al. 2009; Collet et al. 2011; Mikhalovska et al. 2012; Célino et al. 
Table 1 Chemical composition of selected fibre and shiv (Garcia et al. 1998; Bledzhi and Gassan 1999; Vignon et al. 1995; Ross and Mazza 2010; Kostic et al. 2008; Kymäläinen and Sjöberg 2008; Viel et al. 2018)

\begin{tabular}{lllllc}
\hline Specimen & Cellulose $(\%)$ & Lignin $(\%)$ & Hemicellulose $(\%)$ & Pectin $(\%)$ & Wax $(\%)$ \\
\hline Flax fibre & $61.0-71.0$ & $1.8-5.7$ & $18.6-20.6$ & $1.8-2.3$ & $0.5-1.7$ \\
Hemp fibre & $60.0-76.2$ & $3.7-5.7$ & $12.8-22.4$ & $0.9-2.3$ & $0.7-1.7$ \\
Flax shiv & $39.9-41.0$ & $23.0-30.3$ & $25.2-26.8$ & - & - \\
Hemp shiv & $34.0-44.0$ & $22.0-30.0$ & $31.0-37.0$ & $4.0-5.0$ & $0.5-1.4$ \\
\hline
\end{tabular}

2013). Hill et al. studied the water vapour sorption behaviour of a range of natural fibres (jute, flax, coir, cotton, hemp, sitka spruce). They found that the extent of hysteresis exhibited between the adsorption and desorption isotherms was dependent on the fibre type studied (Hill et al. 2009).

Hemp-lime, which is a mixture of hemp shiv, water and lime, has been widely studied as a bio-based building material due to its low thermal conductivity (0.06-0.14 W/m.K) and high moisture buffer value $\left[2.15 \mathrm{~g} /\left(\mathrm{m}^{2} . \% \mathrm{RH}\right)\right]$ (Collet et al. 2013). The literature reveals that the low density, complicated microstructure and high porosity of cell wall play a key role to their low thermal conductivity and high moisture buffer value for bio-based plant building materials (Collet et al. 2008; Collet 2014; Bourdot et al. 2017). Collet et al. (2008) studied the porous structure and water vapour sorption of hemp-based materials and showed that lime-hemp render and hemp mortar contain macro-pores, meso-pores and micro-pores. These pores were associated with measured water vapour sorption isotherms classified as type II. Collet et al. (2013) also reported that the capillary condensation occurs in pores of width from $5 \mathrm{~nm}$ to $40 \mathrm{~nm}$ in the range of relative humidity range $81-97 \%$ RH. This range of pore sizes is observed in the cell wall of hemp shiv. Rahim et al. reported on the sorption isotherm curves of the hemp concrete (HLC) and flax concrete (FLC). HLC reached a lower equilibrium moisture content than FLC because the porosity of flax shiv is smaller than the porosity of hemp shiv, and thus more capillary condensation is promoted, resulting in increased moisture adsorption (Rahim et al. 2015).

The exact mechanisms of moisture sorption in natural plant materials are not yet well understood. Engelund et al. (2013) reported that the moisture molecules can be directly adsorbed by the cell wall polymer of plant materials through the different binding sites, including the hydroxyl $(-\mathrm{OH})$ groups, the carboxyl groups and, if present, the sulfonic acid groups. Most of the absorbed moisture molecules are held in amorphous areas of the cellulose and the hemicellulose and lignin matrix through the hydroxyl groups. Kollmann (1962) reported the sorption isotherm of wood presents an upward bend around 60-70\% RH, which is related to sorption of free water in capillaries due to the micropores in the cell wall. However, Thygesen et al. suggested that the moisture condensation in capillaries is insignificant below 99.5\% RH. Engelund et al. further explained this phenomena by using theoretical calculations (Engelund Emil et al. 2010). Mauze and Stern (1984; Vrentas and Vrentas 1991) reported another potential explanation for this upward curve of the sorption isotherm, which is due to the softening of the amorphous polymers. The sorption hysteresis for wood has been observed over the entire range of relative humidity. There are two main physical explanations for the existence of hysteresis. One explanation refers to narrow connections between large cavities of adjoining pores due to entry pores with small diameter based on the capillary theory of adsorption such as capillary condensation hysteresis; contact angle hysteresis and the ink-bottle effect (Engelund et al. 2013). Second explanation has been suggested that the existence of sorption hysteresis attributes to the process of polymer relaxation in the inter-microfibrillar matrix (Hill et al. 2012).

A better understanding of the moisture sorption mechanism of fibre and shiv of flax and hemp is necessary for developing fibre and shiv-reinforced composite insulation materials. This paper aims to study the effects of the microstructure, chemical composition, pore size distribution and porosity on the hygroscopic behaviour of fibre and shiv. In addition, the moisture sorption properties (sorption 
isotherms) and the enthalpy of heat sorption were evaluated for both shiv and fibre of flax and hemp during the sorption process.

\section{Materials and methods}

The fibre and shiv of hemp and flax used in this study were obtained from the CAVAC Company (France), produced by a mechanical de-fibreing process (shown in Fig. 1). The materials and mechanical de-fibering process used are as reported by Viel et al. (2018). The fibres were composed of bundles containing surface defects such as kink band and microcracking, whilst the shiv exhibited a more regular shape with a smoother surface topography. The particle size of hemp shiv and flax shiv was measured using a digital electronic calliper. The test was repeated three times on different orientations for each shiv. The particles of hemp shiv and flax shiv had a mean length of $17.6 \pm 2.3 \mathrm{~mm}$ and a mean width of $8.4 \pm 1.8 \mathrm{~mm}$ and a mean length of $13.5 \pm 1.6 \mathrm{~mm}$ and $3.3 \pm 0.6 \mathrm{~mm}$, respectively. The protocol used to dry the samples are as reported by Jiang et al. (2018). The bulk densities of hemp shiv and flax shiv were in the range of $85-90 \mathrm{~kg} / \mathrm{m}^{3}$, which is measured based on the followed protocol that was developed by the RILEM Technical Committee 236-BBM (Picandet 2017). The test was repeated three times for each shiv.

The microstructure of the fibre and shiv was observed by a scanning electron microscope (JEOL SEM-6480LV, Tokyo, Japan). The sample preparation for SEM measurement has been reported by Jiang et al. (2018). FTIR transmittance spectra were collected in an attenuated total reflection (ATR) mode with $20 \mathrm{~mm}^{-1}$ resolution and 10 scans were accumulated for each spectrum in the range $6-40 \mathrm{~m}^{-1}$. The thermal properties of the fibre and shiv specimens were studied using a thermal analyser (STA 449, NETZSCH, Germany) under a pure nitrogen atmosphere. The temperature was increased from 25 to $800{ }^{\circ} \mathrm{C}$ at a constant heating rate of $10{ }^{\circ} \mathrm{C} / \mathrm{min}$ with a nitrogen flow of $20 \mathrm{ml} / \mathrm{min}$.

The porosity and pore size distribution of fibre and shiv were analyzed by an Autopore Mercury Porosimeter (PASCAL, Thermo Scientific). This related the radius ( $r$ ) of pores (assumed to be cylindrical) to the imposed pressure $(\mathrm{P})$ using the Washburn equation (Wang et al. 2016):

$\mathrm{P}=(-2 \gamma \cos \theta) / \mathrm{r}$

where $\gamma=$ interfacial energy (surface tension) of mercury, $\theta=$ contact angle of mercury with the material.

The adsorption and desorption of moisture molecules by the fibre and shiv specimens were investigated using a dynamic vapour sorption apparatus (DVS, Surface Measurement Systems, UK). The methods used here are as reported by Hill et al. (2012).

The moisture sorption and heat sorption of bioaggregates were studied by using a simultaneous thermal analyser (STA-449 F3 Jupiter, NETZSCH, Germany) combined with a humidity generator (Modular Humidity Generator, NETZSCH, Germany) and a copper furnace including coupling adapter. A suitable gas flow rate $(100 \mathrm{ml} / \mathrm{min})$ was delivered and controlled by a humidity generator control software to achieve the desired setpoint for humidity. Humidity and temperature values were recorded by means of a humidity sensor which is situated within a heated adapter. To avoid condensation and allow high relative humidity, the experimental temperature setpoint was fixed $5{ }^{\circ} \mathrm{C}$ above the maximum dewpoint. The mass change of the bio-aggregates was measured

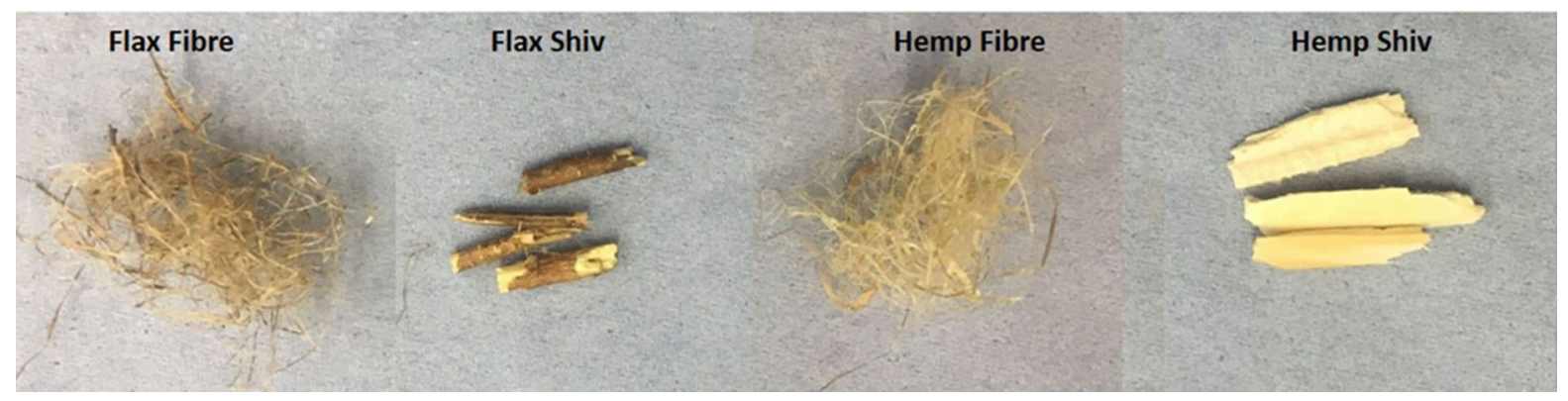

Fig. 1 Optical photos showing the appearance of studied fibre and shiv of flax and hemp 
at different relative humidity (RH) levels (33\%, 54\% and $75 \%$ ) in both increasing and decreasing steps. Each RH level lasted for $3 \mathrm{~h}$ and a microbalance in the STA measured the mass change continuously during the experimentwith a nitrogen flow rate of $20 \mathrm{ml} / \mathrm{min}$ at $30{ }^{\circ} \mathrm{C}$. At the same time, the heat of sorption, which is related to moisture sorption of the specimens, was also measured by the STA.

\section{Results}

\section{Microstructure}

Figure 2 shows the microstructure of the shiv and fibre for hemp and flax. The hemp shiv had a foam-like closed cell structure comprised of continuous cells known as tracheids as shown in Fig. 2a. The larger cells which are similar to vessels in hardwoods were approximately $50-80 \mu \mathrm{m}$ in diameter. Flax shiv (Fig. 2b) had a relatively simple structure compared with hemp shiv. The majority of flax shiv was comprised of long, thin tracheids. The diameter of tracheids was in the range of $20-80 \mu \mathrm{m}$. In the centre of the stem, there were relatively large diameter cells with thin walls. Figure $3 \mathrm{c}-\mathrm{f}$ shows SEM images of hemp fibre and flax fibre. The hemp and flax fibres were in the form of bundles, with elementary fibres joined by middle lamellae. The cross-section of the fibre bundles were irregular and most of them have an ellipsoidal or polygonal shape. The flax fibres $(F)$ were imaged as a partly separated bundle revealing the single fibres. The microstructures of the hemp and flax fibre were similar in terms of their cross-section shape. It was clear that the cell wall microstructure of the hemp and flax shiv was significantly different from the microstructure of the hemp and flax fibres. In addition, the microstructure of hemp shiv was different from that of flax shiv with regard to the thickness of cell wall and arrangement of pores.

\section{FTIR of the shiv and fibres}

Figure 3 shows the FTIR spectra in an ATR mode for shiv and fibre of both hemp and flax. The main peak in the range of 33-35 $\mathrm{m}^{-1}$ was due to the characteristic axial vibration of the hydroxyl group of cellulose (from 2, 3 and 6 carbon of glucose). The adsorption bands at 29.18 and $28.51 \mathrm{~m}^{-1}$ were due to the presence of $\mathrm{C}-\mathrm{H}$ stretch vibration from polysaccharides and $\mathrm{CH}_{2}$ stretch from wax, respectively. The peak at $17.36 \mathrm{~m}^{-1}$ was attributed to $\mathrm{C}=\mathrm{O}$ unconjugated stretching of carboxylic acid or ester of the hemicelluloses and the peak at $12.32 \mathrm{~m}^{-1}$ was associated with $\mathrm{C}-\mathrm{O}$ stretching vibration of acyl group present in the lignin. The peak at around $10.33 \mathrm{~m}^{-1}$ was assigned to $\mathrm{C}=\mathrm{O}$ stretch vibration in the hemicellulose and pectin and the peak at $8.95 \mathrm{~m}^{-1}$ was due to the presence of C-O-C stretch (Pandey 1999; Rana et al. 2010; Esteves et al. 2013). All above peaks can be observed in all four FTIR spectra. There was no essential difference in the FTIR spectra of the studied fibres or shiv. This indicated that all the specimens had a similar chemical structure. However, certain minor differences were observed between fibre and shiv. For instance, the peak at $16.39 \mathrm{~m}^{-1}$ was assigned to $\mathrm{C}=\mathrm{C}$ stretching vibration in the lignin, which is only observed in the FTIR spectrum of hemp shiv and flax shiv. The peaks at $15.06 \mathrm{~m}^{-1}(\mathrm{C}=\mathrm{C}$ aromatic symmetrical stretching) and $14.25 \mathrm{~m}^{-1}(\mathrm{HCH}$ and $\mathrm{OCH}$ in plane deformation) were also only observed in the FTIR spectrum of shiv specimens. Meanwhile, the FTIR spectrum of hemp fibre and flax fibre showed a peak at $10.24 \mathrm{~m}^{-1}(\mathrm{C}-\mathrm{C}, \mathrm{C}-\mathrm{OH}, \mathrm{C}-\mathrm{H}$ ring and side group vibration), which does appear in the FTIR spectrum of shiv specimens. Compared to the FTIR spectra of hemp fibre and flax fibre, both FTIR spectra of hemp shiv and flax shiv showed a strong intensity peaks at $17.36 \mathrm{~m}^{-1}$ and $12.32 \mathrm{~m}^{-1}$. These results indicate that the components of fibres and shiv of flax and hemp include cellulose, hemicellulose, lignin, pectin and waxes. In terms of chemical composition, the shiv had a higher amount of lignin and hemicellulose compared with the fibres, which is in a good agreement with literature findings reported in Table 1.

TGA analyses of the shiv and the fibres

Figure 4 shows the TGA and DTG spectra of fibre and shiv of both hemp and flax at a heating rate of $10{ }^{\circ} \mathrm{C} /$ min under a pure nitrogen atmosphere. The peaks in the DTG curves correspond to points of maximum decomposition slope in the original TGA curves. Results showed that all the specimens have a similar degradation process. All the specimens showed two main decomposition peaks on the DTG thermograph. Initial degradation of both shiv and fibre started at around $220^{\circ} \mathrm{C}$. Hemicellulose started its exothermal 


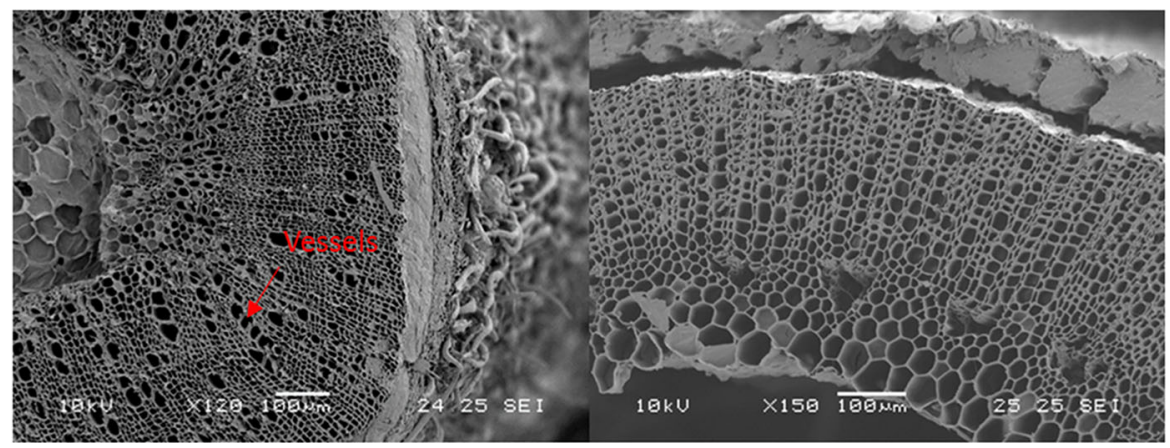

(A)

(B)

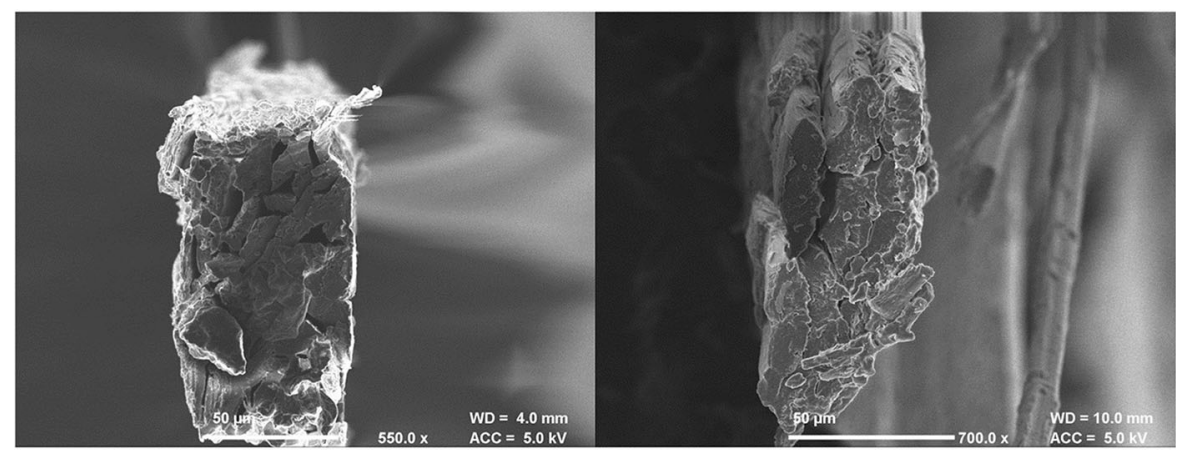

(C)

(D)

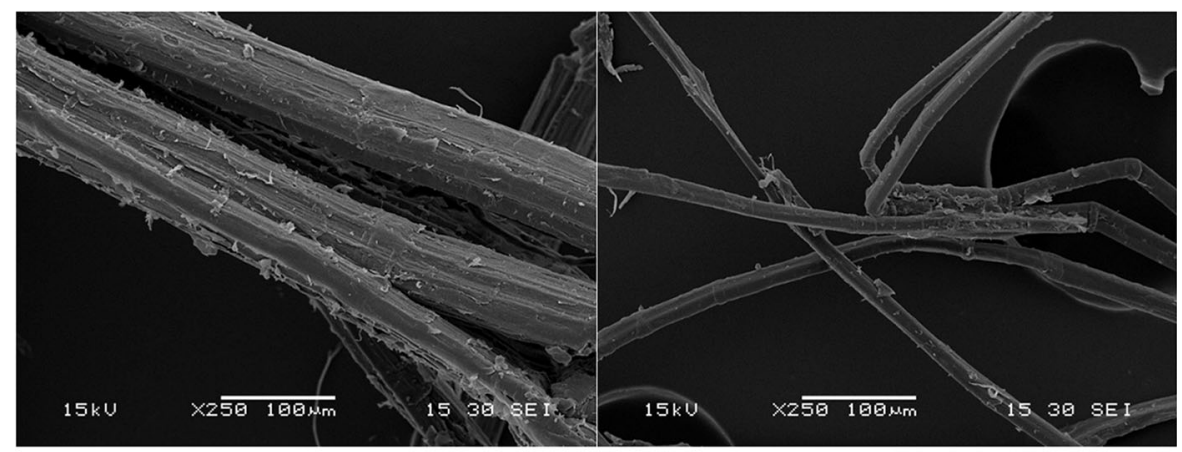

(E)

(F)

Fig. 2 Scanning electron microscope (SEM) images of crosssections of hemp shiv (a), flax shiv (b) fibre bundles can be seen in the outer layer of the sample that meant the separation of the

decomposition at $220-300{ }^{\circ} \mathrm{C}$ and the pyrolysis of cellulose took place between 315 and $400{ }^{\circ} \mathrm{C}$, whereas that of lignin had a broader temperature range between 220 and $600{ }^{\circ} \mathrm{C}$ (Stefanidis et al. 2014). The higher decomposition rate of the shiv between 220 and $260{ }^{\circ} \mathrm{C}$ indicated that the shiv has a much higher content of hemicellulose than the fibres. Both species of fibre showed a higher decomposition rate than shiv between 260 and $400{ }^{\circ} \mathrm{C}$. It followed that the fibre two fractions was not perfect, hemp fibre (c) and flax fibre (d) and SEM images of specimens of hemp fibre (e) and flax fibre (f)

possessed a higher concentration of cellulose than the shiv, because the main decomposition between 300 and $400{ }^{\circ} \mathrm{C}$ correspond to the simultaneous decomposition of cellulose. The data showed that the shiv had a higher mass loss compared to the fibre above $400{ }^{\circ} \mathrm{C}$ as can be seen in Fig. 4a. The mass loss above $400{ }^{\circ} \mathrm{C}$ was assigned to the decomposition of lignin. It indicated that both species of shiv have a higher concentration of lignin than hemp and flax fibre. 


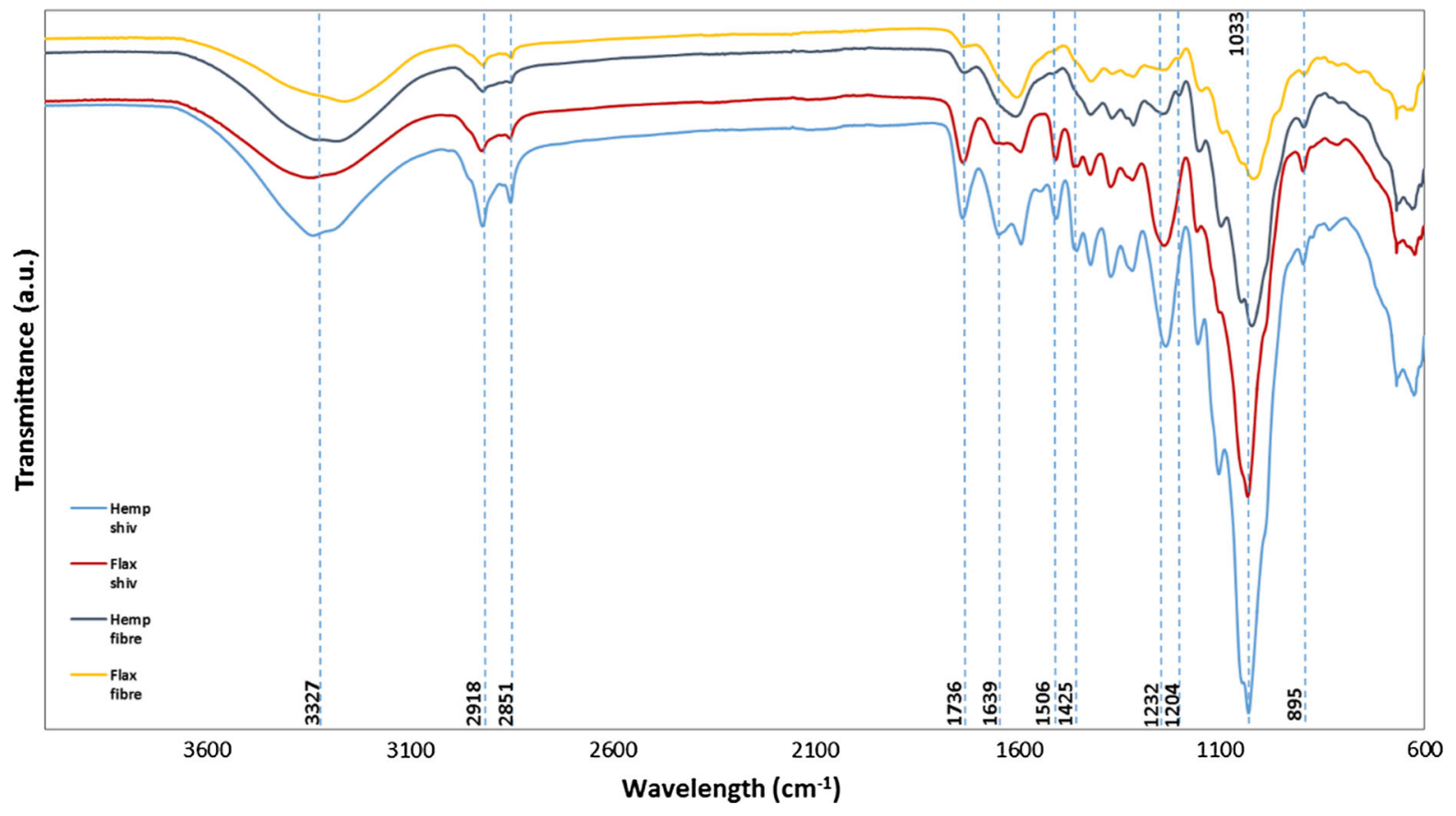

Fig. 3 Fourier transform infrared spectra for shiv and fibre (Hemp and Flax)

Porosity and pore size distribution of shiv and fibres

Table 2 summarises the density and porosity of shiv and fibre specimens obtained by MIP. Shiv showed a higher porosity (hemp: $77.93 \pm 4.05 \%$ and flax: $75.81 \pm 3.36 \%)$ compared to the hemp fibre $(35.71 \pm 2.89 \%)$ and flax fibre $(40.8 \pm 2.03 \%)$. In addition, the apparent densities of the fibre (hemp: $1519.1 \pm 78.9 \mathrm{~kg} / \mathrm{m}^{3}$ and flax: $1518.6 \pm 78.6 \mathrm{~kg} / \mathrm{m}^{3}$ ) were higher than the apparent densities of the hemp shiv $\left(1453.9 \pm 74.1 \mathrm{~kg} / \mathrm{m}^{3}\right)$ and flax shiv $\left(1431.8 \pm 74.9 \mathrm{~kg} / \mathrm{m}^{3}\right)$. Ehrnrooth (1984) reported that the apparent density of the fibres increased with reducing lignin content, and the density of lignin and hemicellulose in situ were measured to be 1397 and $1541 \mathrm{~kg} / \mathrm{m}^{3}$ respectively, whereas the density of cellulose was around $1559 \mathrm{~kg} / \mathrm{m}^{3}$. Stefanidis et al. (2014) also reported that the true density of a cellulose crystal was between 1582 and $1599 \mathrm{~kg} / \mathrm{m}^{3}$, indicating that the fibres have a higher cellulose content than the shiv.

By employing Washburn's Eq. (1), the pore volume distribution and pore size distribution of shiv and fibre can be derived as shown in Fig. 5. Both shiv of hemp and flax had a larger cumulative pore volume $\left(2063-2428 \mathrm{~mm}^{3} / \mathrm{g}\right)$ compared to the fibres $\left(365.71-481.41 \mathrm{~mm}^{3} / \mathrm{g}\right)$. The increase in $\mathrm{Hg}$ uptake was attributed to filling of the pores. There was an initial steep filling of the voids in the range of $10-100 \mu \mathrm{m}$, followed by a plateau in the range of 0.004-10 $\mu \mathrm{m}$ for both hemp fibre and flax fibre. In contrast, the volumetric data showed a slow filling of voids between 80 and $100 \mu \mathrm{m}$ for hemp shiv and flax shiv. Subsequently the flax shiv had a higher increase of $\mathrm{Hg}$ uptake around $20 \mu \mathrm{m}$ and a lower increase of $\mathrm{Hg}$ uptake around $0.5 \mu \mathrm{m}$ compared to the hemp shiv. Figure $5 \mathrm{~b}$ shows the pore size distribution of specimens corresponding to the filling of $\mathrm{Hg}$ under different pressures. Figure $5 \mathrm{~b}$ shows hemp fibre and flax fibre have a pore size distribution from 5 to $100 \mu \mathrm{m}$ and both hemp shiv and flax shiv showed a bimodal pore size distribution with two clearly separated peaks. For the hemp shiv, the main pore diameter ranged from 0.03 to $1 \mu \mathrm{m}$ and the second pore diameter peak was between 20 and $80 \mu \mathrm{m}$. On the other hand, flax shiv showed the main pore diameter ranging from $5 \mu \mathrm{m}$ to $50 \mu \mathrm{m}$ and the second pore diameter was between 0.03 and $50 \mu \mathrm{m}$. Nanoporosity was not observed, and smaller pores of around $3 \mathrm{~nm}$ had a lower peak 
Fig. 4 TGA (a) and DTG (b) curves of hemp and flax fibre and shiv in a nitrogen atmosphere

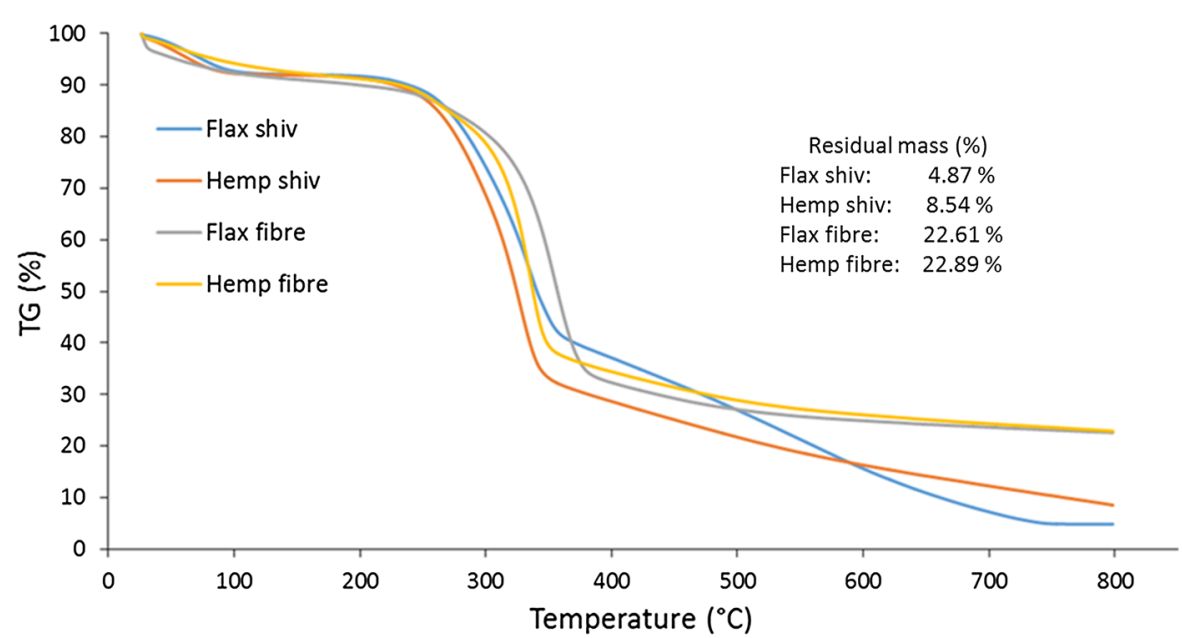

(A)

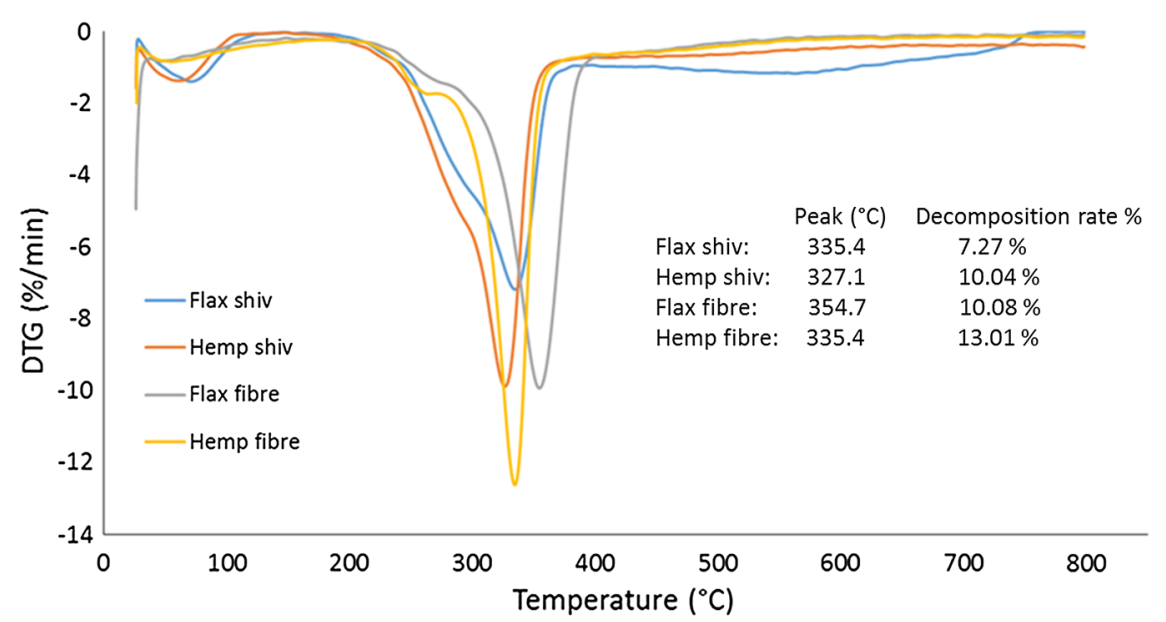

(B)

Table 2 Total intruded volume, Bulk density, Envelope density, Apparent density and Accessible porosity determined by Mercury intrusion porosimetry

\begin{tabular}{lclllr}
\hline Specimen & $\begin{array}{l}\text { Total intruded } \\
\text { volume }\left(\mathrm{mm}^{3} / \mathrm{g}\right)\end{array}$ & $\begin{array}{l}\text { Bulk density } \\
\left(\mathrm{kg} / \mathrm{m}^{3}\right)\end{array}$ & $\begin{array}{l}\text { Envelope density } \\
\left(\mathrm{kg} / \mathrm{m}^{3}\right)\end{array}$ & $\begin{array}{l}\text { Apparent density } \\
\left(\mathrm{kg} / \mathrm{m}^{3}\right)\end{array}$ & $\begin{array}{l}\text { Accessible porosity } \\
(\%)\end{array}$ \\
\hline Flax shiv & $2063.1 \pm 108.6$ & $367.4 \pm 18.9$ & $367.6 \pm 19.2$ & $1431.8 \pm 74.9$ & $75.81 \pm 3.36$ \\
Flax fibre & $481.4 \pm 25.1$ & $847.6 \pm 27.3$ & $850.2 \pm 26.8$ & $1519.1 \pm 78.9$ & $40.8 \pm 2.03$ \\
Hemp shiv & $2428.8 \pm 123.5$ & $320.9 \pm 16.5$ & $321.3 \pm 17.4$ & $1453.9 \pm 74.1$ & $77.93 \pm 4.05$ \\
Hemp fibre & $365.7 \pm 21.3$ & $976.4 \pm 33.2$ & $992.4 \pm 35.7$ & $1518.6 \pm 78.6$ & $35.71 \pm 2.89$ \\
\hline
\end{tabular}

intensity, due to the limit of the sensitivity of MIP technique (pores below $3.7 \mathrm{~nm}$ were not measured and pores above $100 \mathrm{~nm}$ were excluded). The results showed agreement with the SEM images (Fig. 2).
Moisture sorption behaviour of shiv and fibre

In view of the variability of natural specimens, preliminary studies were employed here to measure the reproducibility of the sorption process using 
Fig. 5 Pore volume distribution (a) and pore size distribution (b) of shiv and fibre (Flax and Hemp)

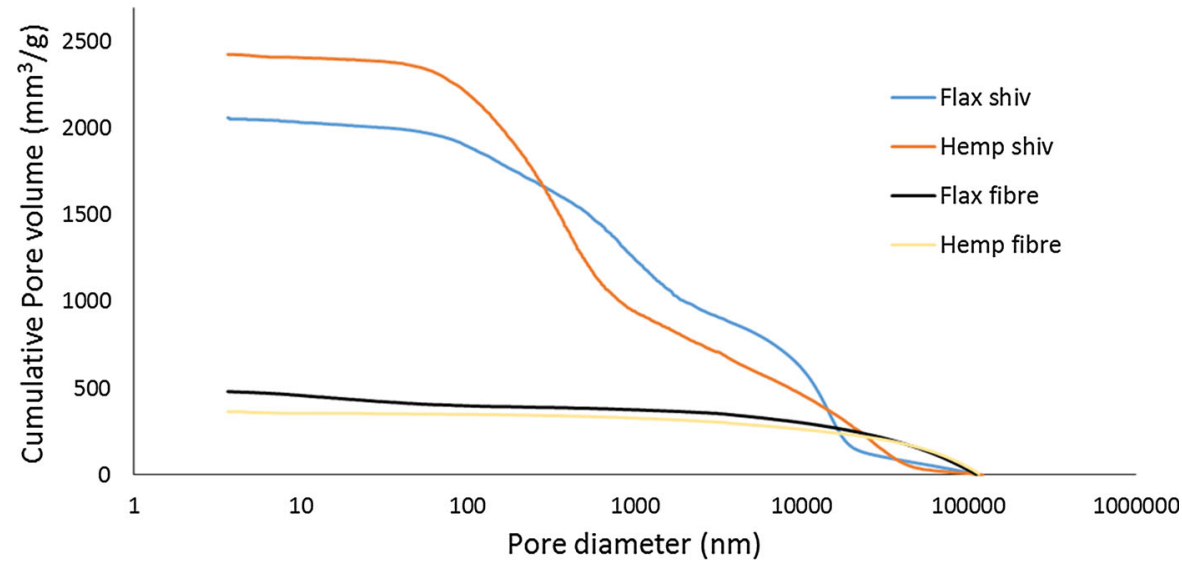

(A)

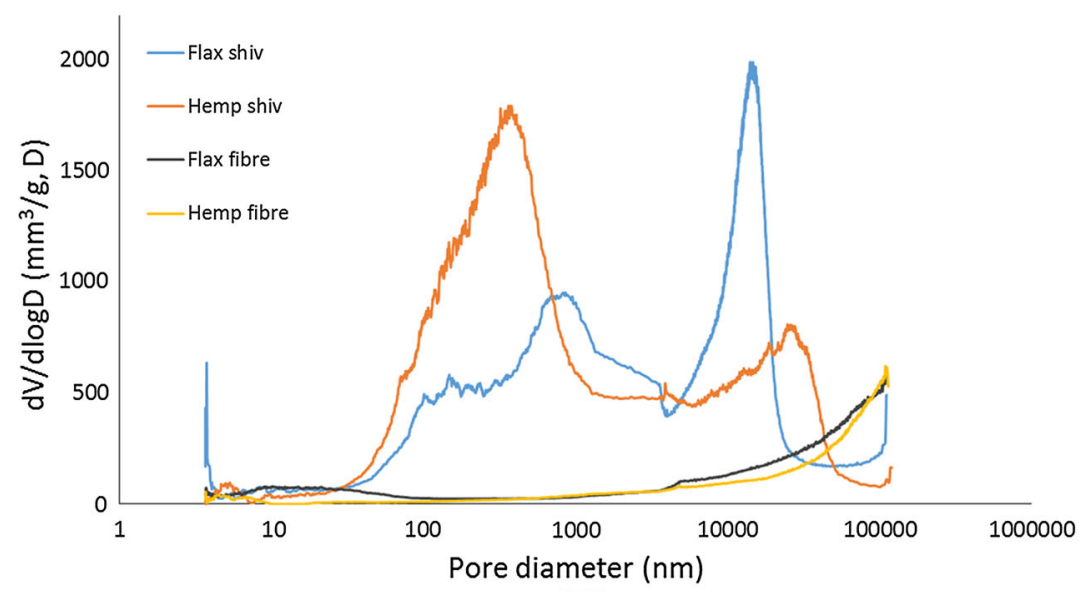

(B) specimens of flax fibre, hemp fibre, flax shiv and hemp shiv. The sorption curves for both hemp and flax fibre and shiv are presented in Fig. 6. These sorption curves show that the data for different specimens of the same fibre/shiv type were reproducible over most of the RH range studied. According to IUPAC classification (Thommes et al. 2015), all specimens studied exhibited the type II-isotherm curves, which represents the adsorption behaviour of macro-porous and non-porous adsorbents (Brunauer et al. 1938; Thommes et al. 2015). A very steep slope especially at the higher RH was observed for hemp fibre and hemp shiv as seen in Fig. 6a, b. Hemp shiv and hemp fibre exhibited higher moisture content on adsorption compared to flax shiv and flax fibre between 80 and $90 \% \mathrm{RH}$.

The individual moisture adsorption and desorption isotherms over three sorption cycles for the flax fibre, hemp fibre, flax shiv and hemp shiv are plotted in
Fig. 7. The absolute hysteresis, which was obtained by subtracting the adsorption from desorption isotherm loop moisture content values for the different specimen over the three cycles, is given in Fig. 8. The sorption isotherms for the flax fibre, hemp fibre and flax shiv specimens were reproducible. For the hemp shiv, the moisture content value of first sorption cycle was higher than the second and third cycles. The hysteresis decreased between the first and subsequent cycles. The desorption curve of the isotherm remained the same. In addition, results showed the hemp shiv and flax shiv exhibited a higher hysteresis value around $2.5 \%$ for second and third cycles at RH $70 \%$. Meanwhile, there was a significant decrease in the sorption hysteresis for hemp fibre and flax fibre (approximately $1.2 \%$, average value of three cycles at RH $70 \%$ ). 


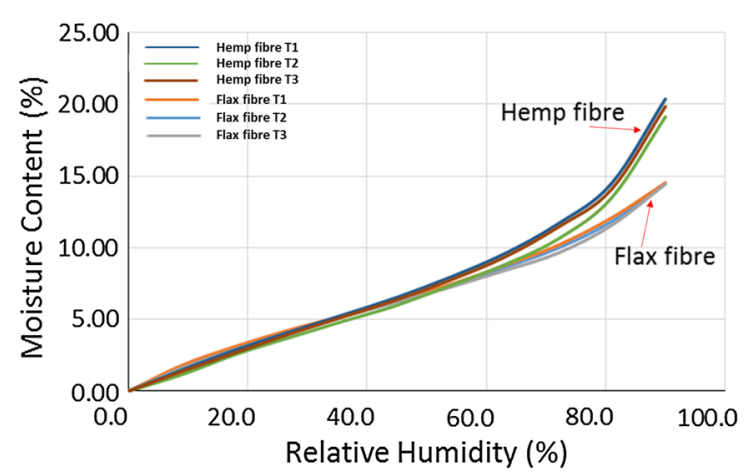

(A)

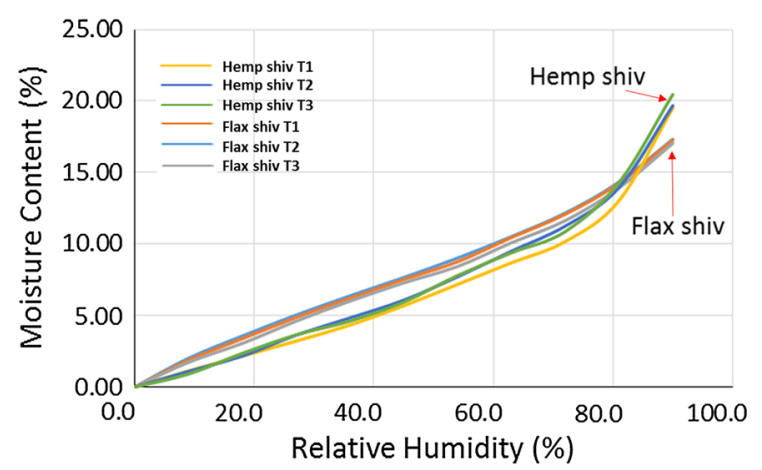

(B)

Fig. 6 Comparison of moisture adsorption behaviour of fibre (a) and shiv (b) (Flax and Hemp) at $23{ }^{\circ} \mathrm{C}$. The data for different specimens of the same fibre and shiv were reproducible over most of the $\mathrm{RH}$ range studied

The differences in hysteresis behaviour are more clearly illustrated when the curves are overlaid as seen in Fig. 9. Hemp fibre and flax fibre showed a similar hysteresis around $1 \%$ in the whole part of the hygroscopic range. However, hemp shiv and flax shiv exhibited an increasing hysteresis in the lower part of the hygroscopic range. Hemp shiv and flax shiv exhibited a significantly higher sorption hysteresis compared with hemp fibre and flax fibre between 20 and $80 \%$ RH.

The mass change of moisture content at varying humidity range for hemp shiv, hemp fibre, flax shiv and flax fibre is shown in Fig. 10. All specimens had a similar mass change of moisture content below $70 \%$ RH. The moisture content of hemp shiv and hemp fibre significantly increased compared to flax shiv and flax fibre between RH72 and RH90\%.

Figure 11 shows that hemp shiv did not reach the equilibrium $(\mathrm{dm} / \mathrm{dt}=0.002 \%)$ between 81 and $90 \%$ RH before moving to the next step after reaching the max time limit $(360 \mathrm{~min})$. The other three specimens reached equilibrium within the set time limit (360 min) between 81 and 90\% RH. In addition, it was observed that the equilibration time for both fibres were shorter than the equilibration time for both shiv.

\section{Heat sorption behaviour of shiv and fibre}

The moisture and heat of sorption characteristics of plant material can provide interesting insights into the hygrothermal behaviour of these materials. Figure 12 presents the change of the moisture content and the enthalpy of heat of sorption at various relative humidity levels at $30{ }^{\circ} \mathrm{C}$ for hemp shiv. Similar results had also been observed for hemp fibre, flax shiv and flax fibre as seen in Table 3. All specimens absorbed higher amounts of moisture content (around $0.24 \mathrm{wt} \%$ / $\mathrm{RH} \%$ ) at high relative humidity between $\mathrm{RH} 54$ and RH 75\% compared to moisture content change at low relative humidity $(0-33 \%)$ and medium relative humidity $(33-54 \%)$. For the desorption process, the hemp shiv and flax shiv showed a lower mass percentage change between RH 54 and RH 75\% and a higher mass percentage change between RH 0 and RH 33\% compared to their adsorption process. On the contrary. hemp fibre and flax fibre showed a similar mass change percentage between RH 0 and RH $75 \%$. Thus, the hysteresis of moisture inside shiv was higher than hysteresis inside fibre and the hysteresis effect was more pronounced in high water activity regions, which was in good agreement with DVS results. In addition, the difference in heat of adsorption and desorption was independent of the change in moisture content. The enthalpy of heat of sorption at lower RH $(<33 \%)$ was much higher the enthalpy of heat of sorption at higher $\mathrm{RH}(54 \%$ and $75 \%)$ for both adsorption and desorption processes. The enthalpy change over the full range of humidity was greater than the heat of vaporisation of liquid water $(2257 \mathrm{~kJ} /$ $\mathrm{kg})$ at $30{ }^{\circ} \mathrm{C}$.

\section{Discussion}

Previous literature studies have reported that water can be found in constitutive, bound or free forms in natural plant material (Berthold et al. 1998; Mokhothu and john 2015). The constitutive water belongs to part of 
Fig. 7 Moisture adsorption and desorption behaviour for flax fibre, hemp fibre, flax shiv and hemp shiv at $23{ }^{\circ} \mathrm{C}$
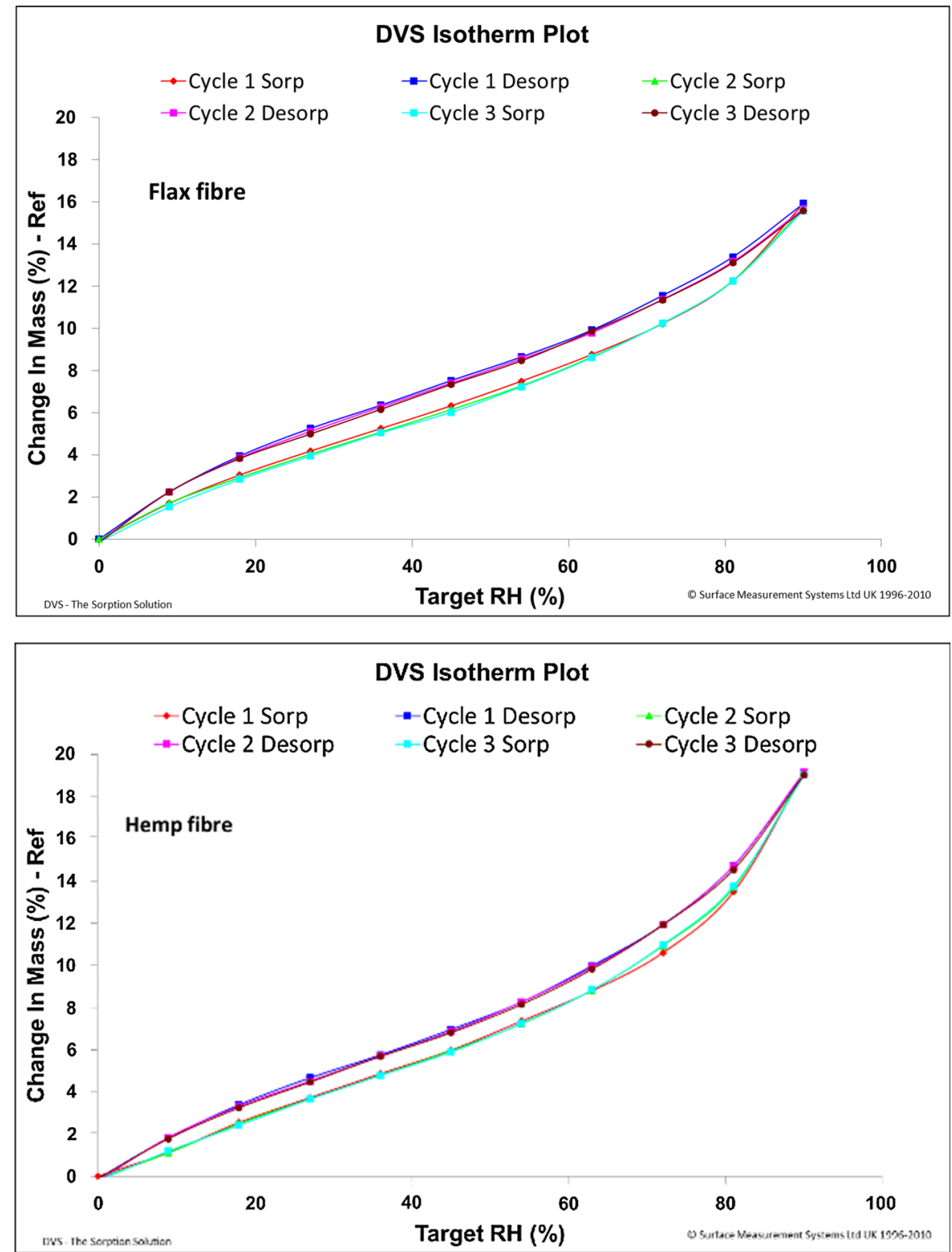

the cell walls which was difficult to remove. The bound water was linked by hydrogen bonds to the cell wall. Free water was the liquid water stored inside the lumens. The water penetrated in the lumens by capillary forces and then diffused into the cell wall by hydrogen bonding force. The penetration of water molecules induced some swelling of the cell wall (Nakamura et al. 1981; Berthold et al. 1994, 1998; Bouguerra et al. 1999; Hill et al. 2010, 2012; Célino et al. 2013; Engelund et al. 2013; Mokhothu and John 2015). Skaar (1984) defined the fibre saturation point
(FSP) when the sample contained no free water and no bound water had been desorbed from the cell wall materials. The fibre saturation points for different natural plant materials were slightly different depending on structure and chemical compositions of the cell wall and normally ranged from 26 to $32 \%$ moisture content.

In this study, the plant-water relations below the fibre saturation point were investigated. The results from these experiments showed that the moisture in the cell wall of the specimens can be removed without 
Fig. 7 continued
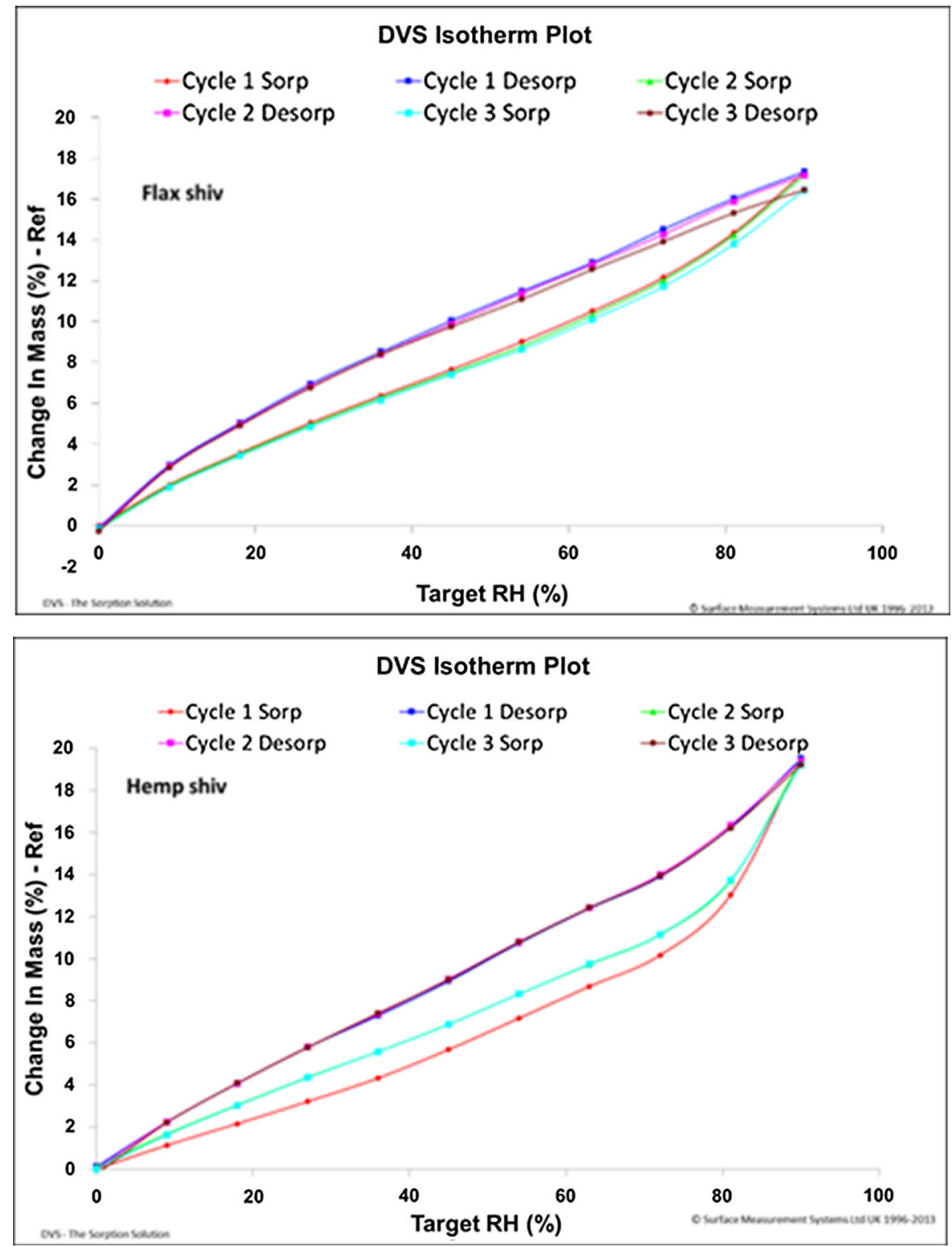

high temperatures. It means that the water is held preferentially in the cell walls as bound water. Figure 7 showed that some of the water molecules had been adsorbed on the surface of cell wall by the hydrogen bonding force. Some of the water molecules were not free to enter the gas phase due to the interactions within the surface of cell wall. The SEM and MIP results showed that the shiv specimens have a larger surface area, wide range of pore distribution and higher porosity compared to the fibre specimens. However, the moisture content at different humidity levels remained more or less similar, regardless of whether the specimen is shiv or fibre. It indicated that the large pores within the tracheids and pith did not affect the adsorption of moisture in the specimens and the available number of hydroxyl groups was more or less independent of the macroscopic surface area of the specimen.

At molecular/atomic level, the cell wall can be considered as a micro-mesoporous material. Although the sorption isotherms of all specimens are generally similar in shape, there are still considerable variations 
Fig. 8 Hysteresis between adsorption and desorption curves (obtained by subtraction of equilibrium moisture contents) for flax fibre, hemp fibre, flax shiv and hemp shiv at different values of relative humidity at $23{ }^{\circ} \mathrm{C}$

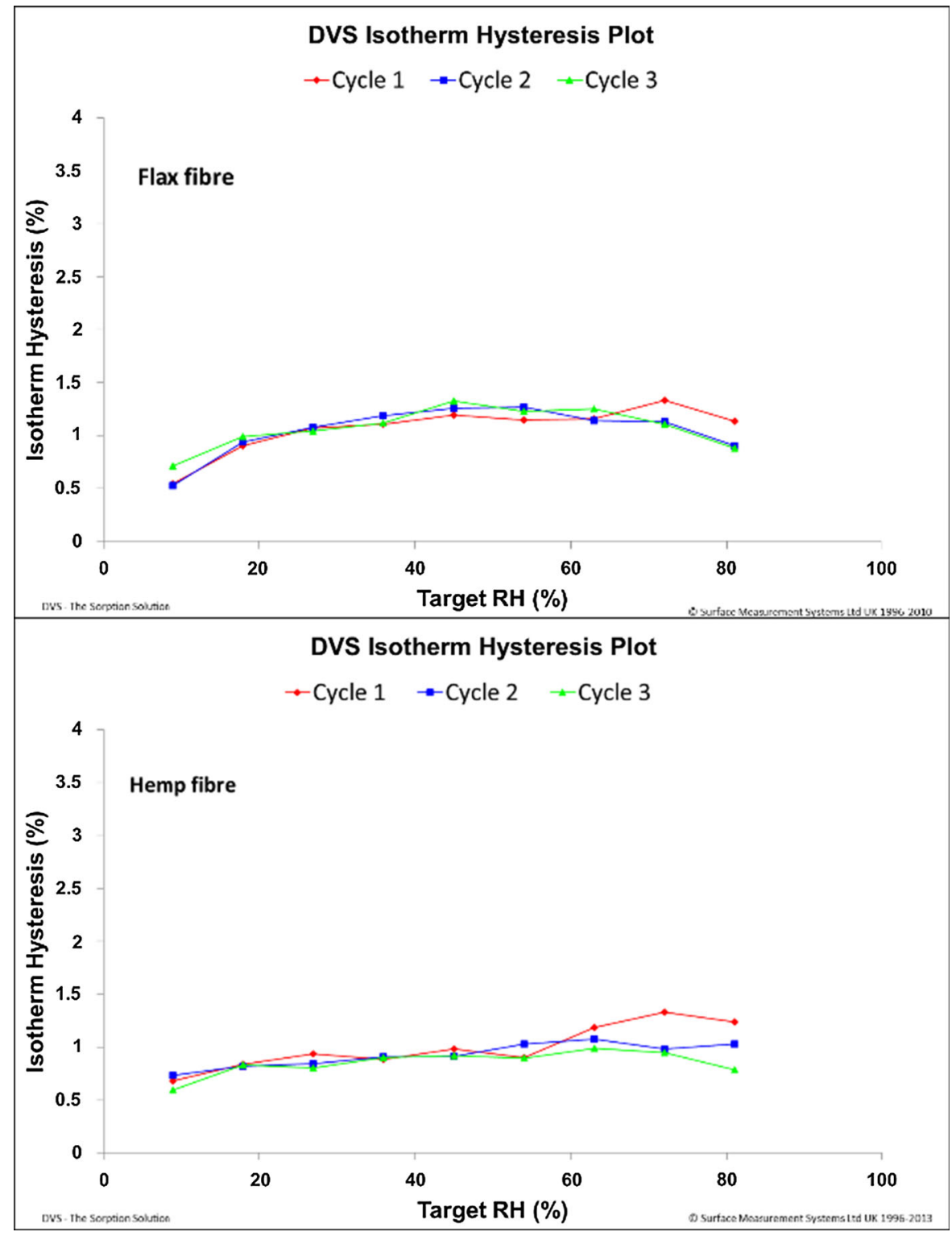

among them with respect to the absolute values of hygroscopicity. Figures 6 and 10 showed the variation was because of difference in the species. The cell wall of a plant is a complex structure, and the chemical composition and microstructure of cell wall vary with the cell type. In previous publications, the single middle lamellae $(\mathrm{ML})$ and primary wall $(\mathrm{P})$ of hemp shiv were found to have thickness of $30-50 \mathrm{~nm}$ and 70-110 nm, respectively (Thygesen et al. 2006; Jiang et al. 2018). The secondary cell wall was found to have a $100-130 \mathrm{~nm}$ thick $\mathrm{S} 1$ layer and a $3-13 \mu \mathrm{m}$ thick S2 layer. The major layers were constructed of $100 \mathrm{~nm}$ thick lamellae. Whereas, the lamellae of flax varied in thickness from 100 to $200 \mathrm{~nm}$ (Jiang et al. 2018). The thickness of the secondary cell wall was a 5.5-8.2 $\mu \mathrm{m}$ (His et al. 2001). The difference of moisture content between hemp and flax at higher relative humidity may be because of the difference in pore size within the cell wall. According to the literature, capillary suction begins at higher relative humidity due to the presence of nanopores in the cell wall (Skaar 1984). Details of the formation, arrangement and 
Fig. 8 continued

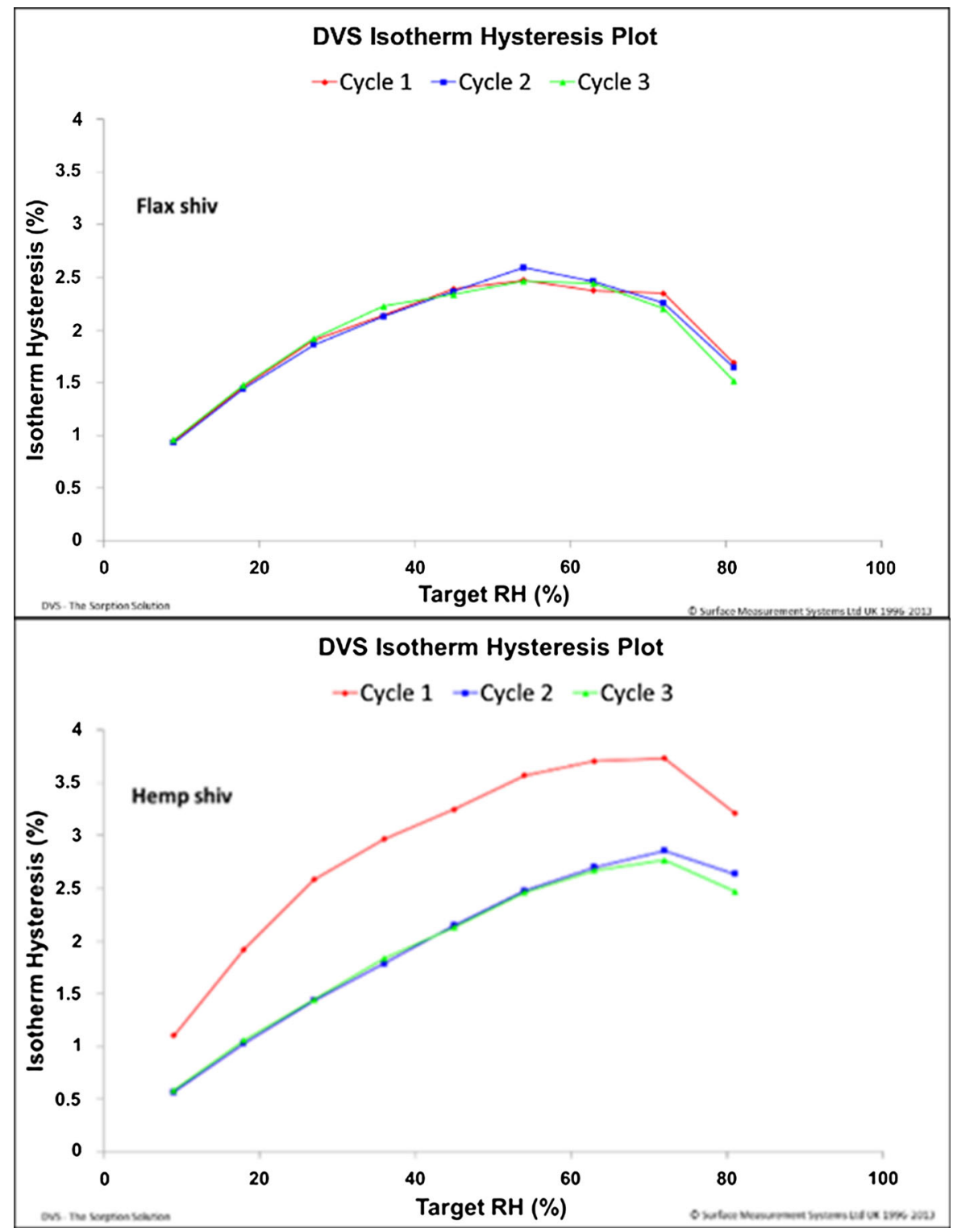

composition of the layers need to be determined in order to understand their influence on water sorption.

The chemical components of the cell wall play a big role on their capacity to bind water. Siau (1984), Skaar (1984) explained that the cell wall of plant contains cellulose, hemicelluloses and lignin. All of these polymers have hydroxyl groups, which can adsorb water molecules by hydrogen-bonding force. The cellulose and hemicellulose have more hydroxyl groups to bind water molecules than lignin, but hydroxyl groups of cellulose are inaccessible to water molecules due to the crystalline regions of the cellulose. This indicated that the moisture content would increase as the relative proportion of hemicelluloses increases, and would decrease as the relative proportion of lignin increases. However, it was observed in this work that both fibre and shiv from both species had a similar moisture content at a particular relative humidity, even though they had a totally different content of cellulose, hemicellulose and lignin because the shiv had a higher proportion of lignin and hemicellulose compared to the fibres, they had sorption capacities either side of the value for cellulose. The accurate sorption capacity of lignin, 
Fig. 9 Graph comparing the hysteresis (cycle 2) between adsorption and desorption curves for flax fibre, hemp fibre, flax shiv and hemp shiv at $23{ }^{\circ} \mathrm{C}$

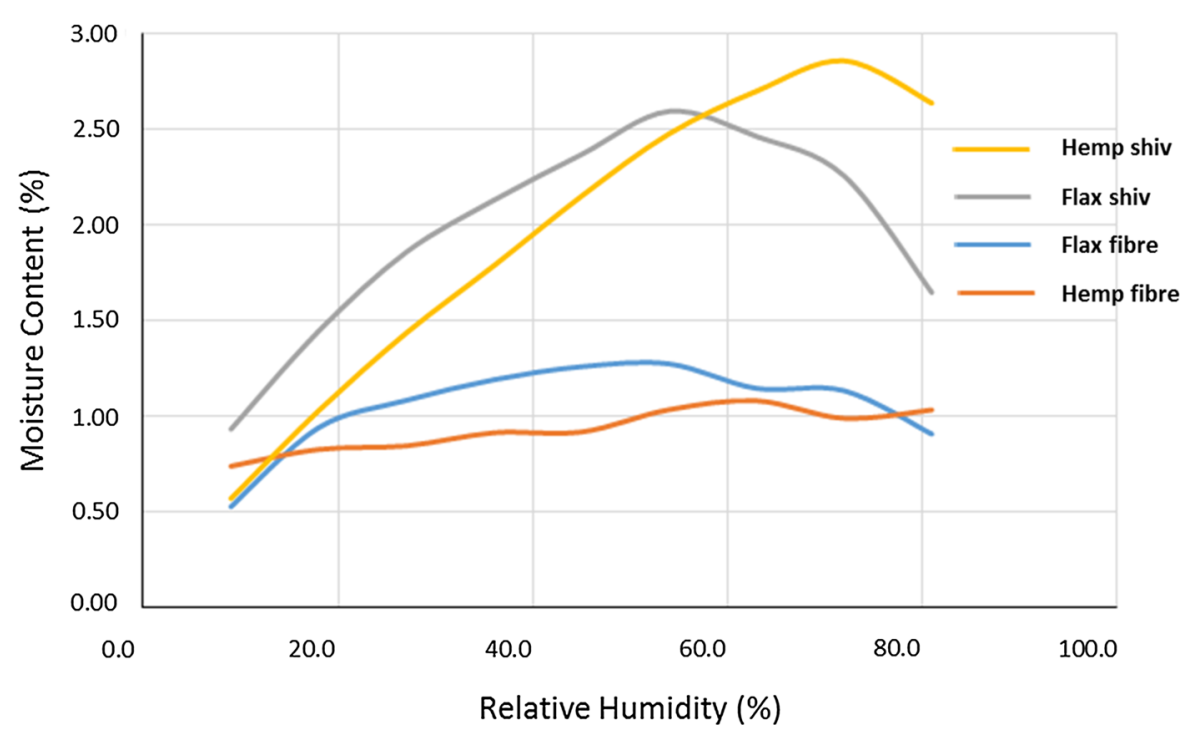

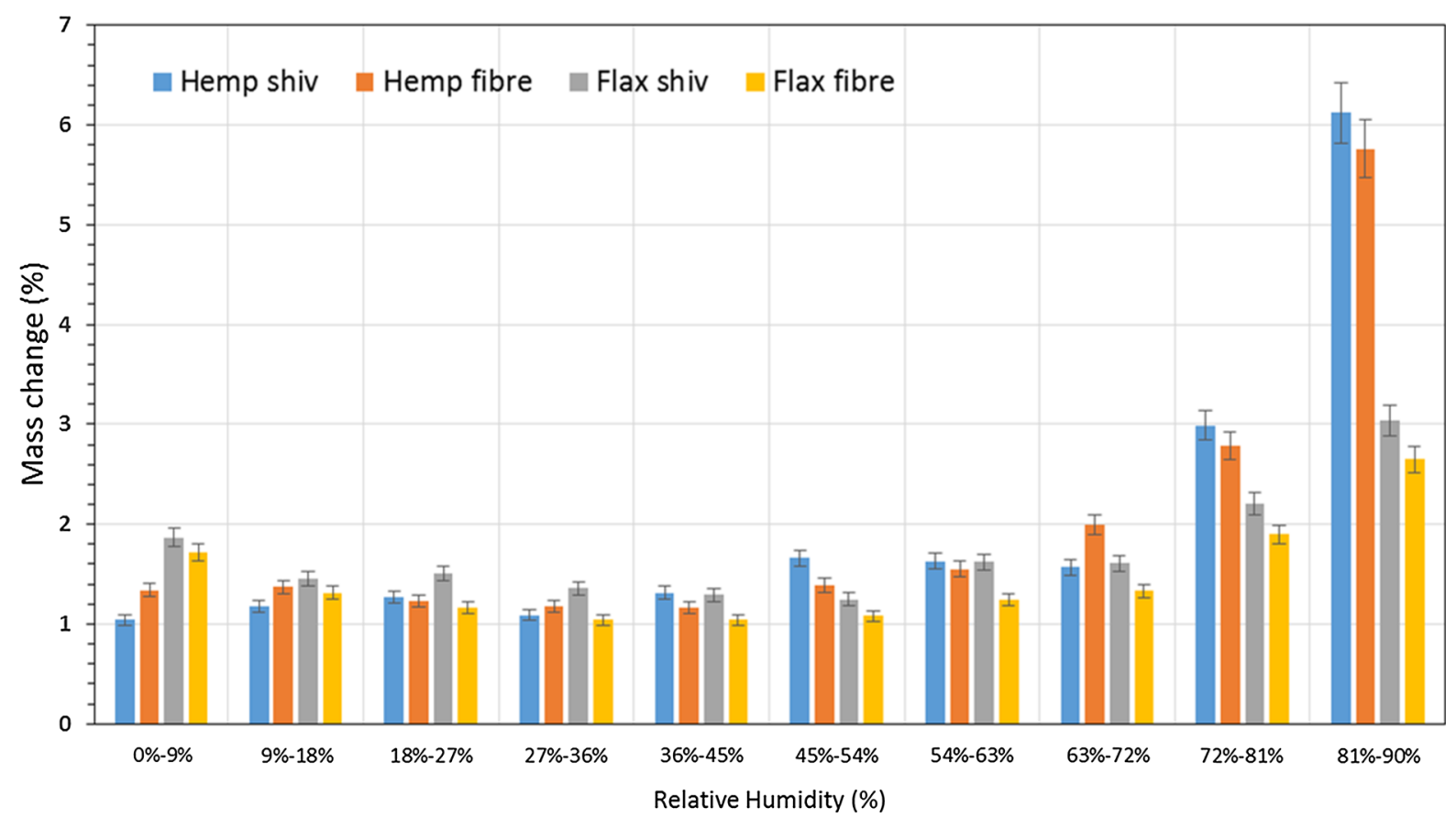

Fig. 10 Graph comparing the mass changes (cycle 2-average value of three specimens of the same fibre and shiv) among the different relative humidity ranges for flax fibre, hemp fibre, flax shiv and hemp shiv at $23{ }^{\circ} \mathrm{C}$

hemicellulose and cellulose need to be further studied and the crystalline regions and amorphous regions of cellulose also need to be further investigated.

The hysteresis for all specimens has been observed to span over the full range of measured relative vapour pressures. As discussed in the introduction, there is a difference of opinion about the mechanism of hysteresis. One hypothesis was attributed to the capillary theory of adsorption due to the micropore in the cell wall and another hypothesis was due to polymer relaxation in the cell wall matrix. In our study, Figs. 6 and 10 showed that hemp shiv and hemp fibre had a similar sorption behaviour, which was slightly different to the sorption behaviour of flax shiv 


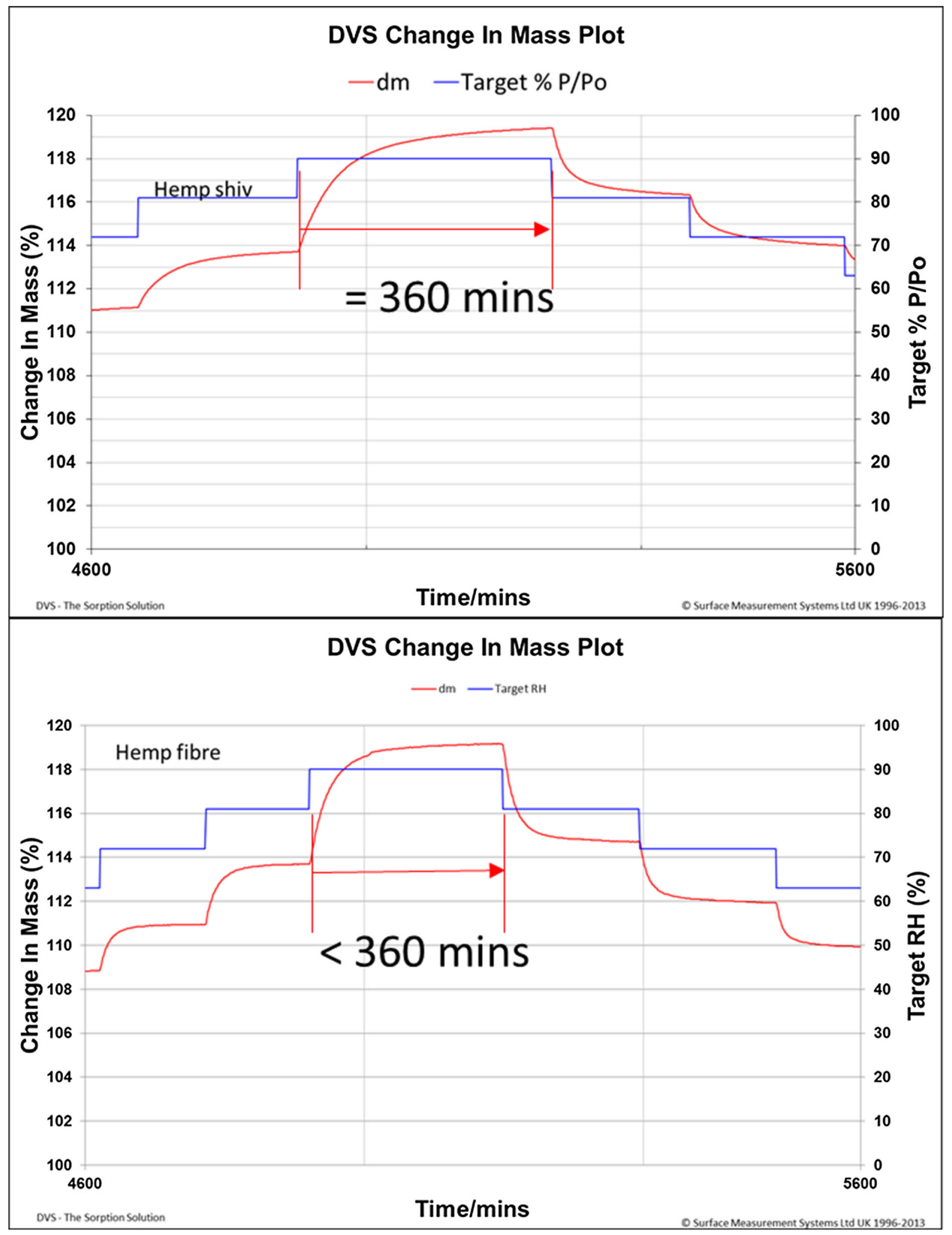

Fig. 11 Graph comparing the time changes between $81 \% \mathrm{RH}$ and $90 \% \mathrm{RH}$ for flax fibre, hemp fibre, and flax shiv and hemp shiv at $23{ }^{\circ} \mathrm{C}$ 


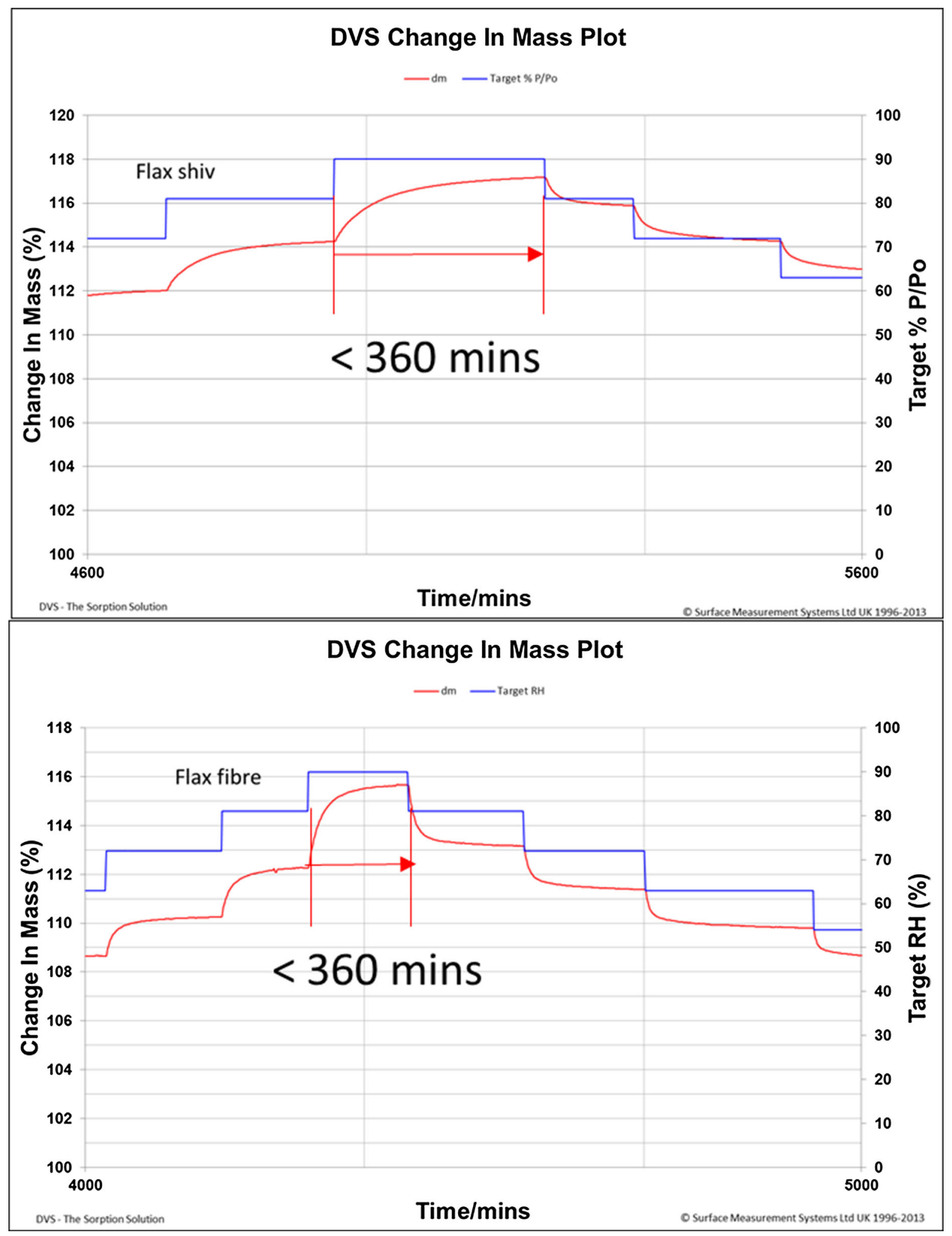

Fig. 11 continued 


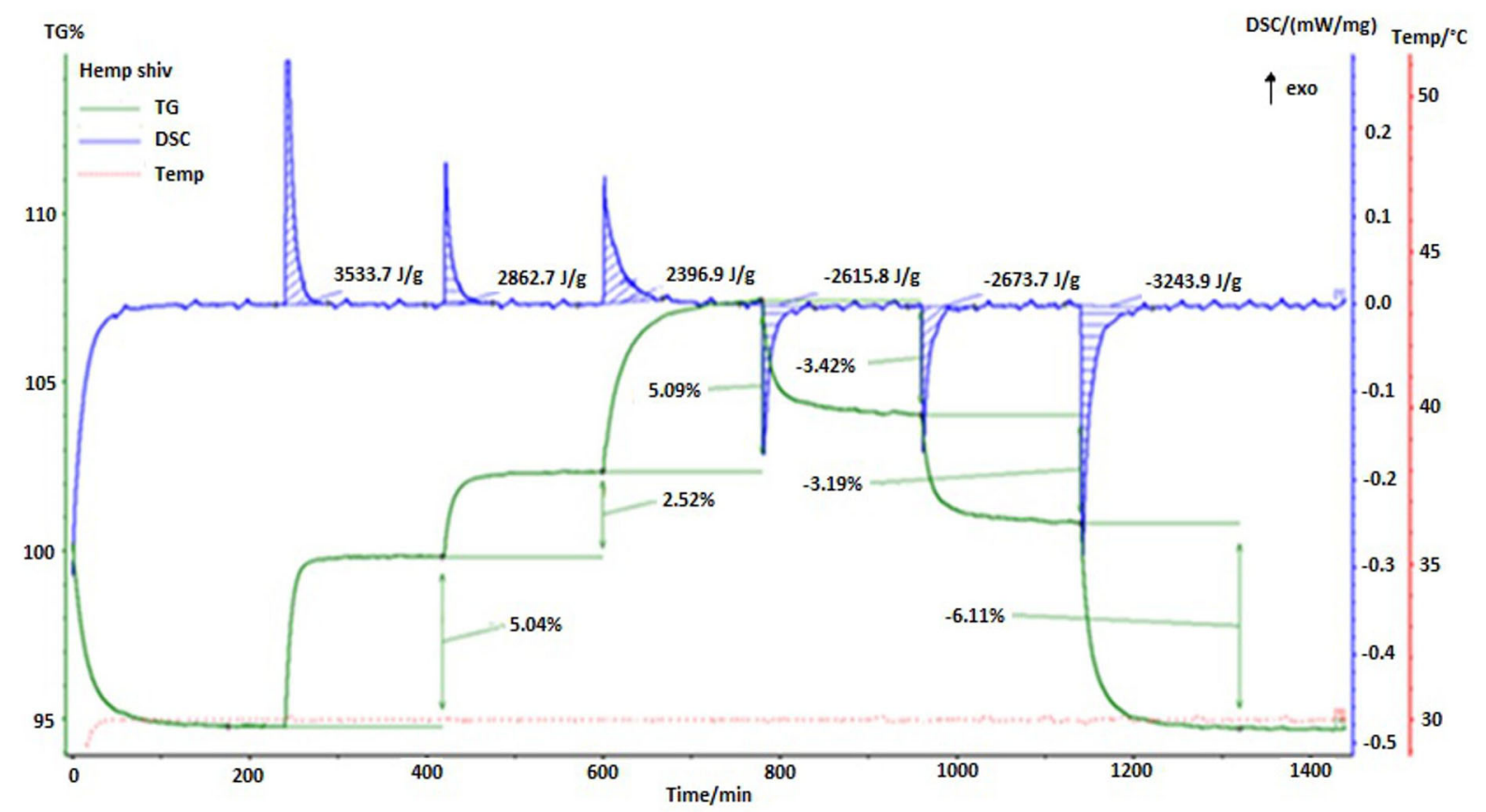

Fig. 12 Mass change percentage of moisture content for hemp shiv at different RH $(33 \%, 54 \%, 75 \%)$ and enthalpy of heat sorption for hemp shiv at different $\mathrm{RH}(33 \%, 54 \%, 75 \%)$ under $30^{\circ} \mathrm{C}$

Table 3 Mass change percentage of moisture content and enthalpy of heat sorption for hemp shiv, hemp fibre, flax shiv and flax fibre at different $\mathrm{RH}$ levels $(33 \%, 54 \%, 75 \%)$ under $30{ }^{\circ} \mathrm{C}$

\begin{tabular}{|c|c|c|c|c|c|}
\hline \multirow[t]{2}{*}{ Name } & \multirow[t]{2}{*}{ Humidity (\%) } & \multicolumn{2}{|c|}{ Mass change (wt\%/RH \%) } & \multicolumn{2}{|c|}{ Heat sorption $(\mathrm{kJ} / \mathrm{kg})$} \\
\hline & & Adsorption & Desorption & Adsorption & Desorption \\
\hline \multirow[t]{3}{*}{ Hemp shiv } & 33 & 0.15 & 0.19 & 3533.7 & 3243.9 \\
\hline & 54 & 0.12 & 0.15 & 2862.7 & 2673.7 \\
\hline & 75 & 0.24 & 0.16 & 2396.9 & 2615.8 \\
\hline \multirow[t]{3}{*}{ Hemp fibre } & 33 & 0.13 & 0.14 & 3045.3 & 2884.3 \\
\hline & 54 & 0.13 & 0.14 & 2962.5 & 2644.8 \\
\hline & 75 & 0.24 & 0.22 & 2654.3 & 2628.5 \\
\hline \multirow[t]{3}{*}{ Flax shiv } & 33 & 0.15 & 0.2 & 3464.9 & 3163.2 \\
\hline & 54 & 0.16 & 0.16 & 3123.9 & 2760 \\
\hline & 75 & 0.26 & 0.17 & 2747.2 & 2693.8 \\
\hline \multirow[t]{3}{*}{ Flax fibre } & 33 & 0.13 & 0.13 & 3505.7 & 3040.1 \\
\hline & 54 & 0.11 & 0.12 & 3125.3 & 2739.1 \\
\hline & 75 & 0.22 & 0.20 & 2854.1 & 2710.7 \\
\hline
\end{tabular}

and flax fibre due to the thickness which vary with the cell type. It meant that the micropores in the cell wall for hemp and flax were different. Figure 9 showed that both hemp shiv and flax shiv had a higher hysteresis than hemp fibre and flax fibre. It can be concluded that the micropores in the cell walls of hemp and flax do not significantly affect the hysteresis of sorption. Furthermore, the hemp shiv and flax shiv had similar proportions of chemical composition (proportion of cellulose, hemicellulose and lignin), which were considerably different from that of hemp fibre and flax fibre. Both hemp shiv and flax shiv had higher lignin contents compared to hemp fibre and flax fibre. It indicated that the hysteresis is dependent on the lignin content and independent of the micropores in the cell wall. This is the first time that difference in the 
A

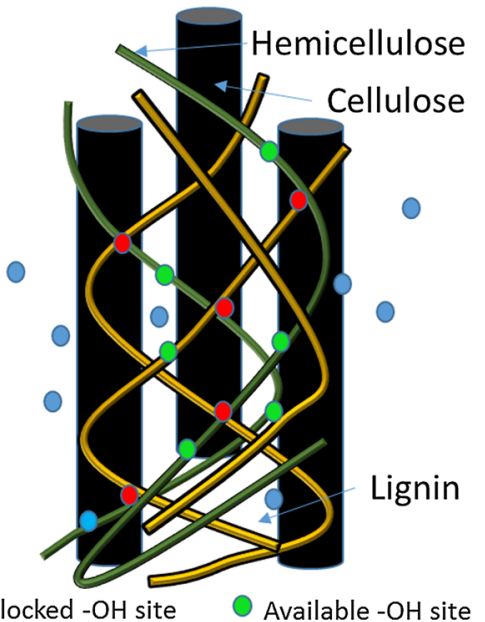

Blocked -OH site Available -OH site

Water vapour molecule

C

Sorption sites
B
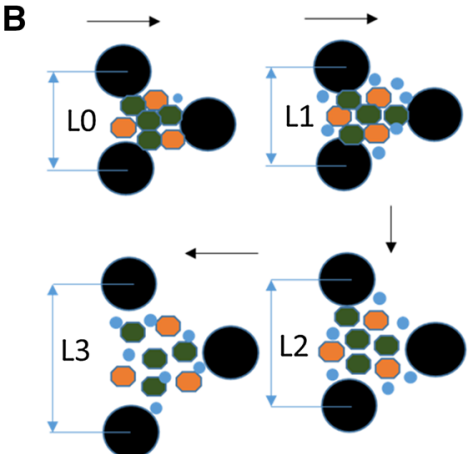

Lignin

Cellulose

Hemicellulose

- Water molecule

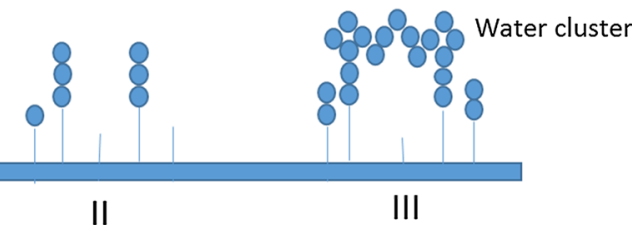

Fig. 13 a Minimal 3D model of water vapour molecules sorption process in bio-based plant materials. b Cross sectional view of biomass matrix: Cellulose crystals (black) are separated by hemicellulose and lignin bundles dry (L0), during hydration, the separation between the cellulose/matrix polymer bundles surface increases $(\mathrm{L} 3>\mathrm{L} 2>\mathrm{L} 1>\mathrm{L} 0)$. With the increase in

sorption isotherm between the first and subsequent sorption cycles for the hemp shiv has been reported. Popescu and Hill reported that a difference was found in the sorption isotherm for the first and second sorption cycles for naturally aged Tilia cordata Mill wood between 60 and $80 \% \mathrm{RH}$. They assumed a possible annealing effect associated with plasticisation of the cell wall polymetric matrix occurring at high moisture contents (Popescu and Hill 2013). This is not in good agreement with this study from the results that had been observed. The potential for the variation between first and subsequent sorption cycles for hemp shiv is associated with possible difference in fine cell wall microstructure such as the structure of bordered pits or extractive content.

According to the findings in this study, the binding force was stronger for the initial layer of water molecules and then reduced for the successive layers. The total enthalpy change over the full range of humidity was greater than the heat of vaporisation of liquid water. The water vapour molecules sorption process in bio-based cellulose materials has been shown in Fig. 13. It can be assumed the water this soften space, water vapour molecules can penetrate into the blocked space at a lower relative humidity. c Schematic representation of water vapour adsorption regime on cell wall of bio-based plant materials involving Monolayer sorption-I, Multilayer sorption-II and formation of water cluster (Capillary condensation)-III

molecules occupy the spaces between the microfibils in the cell wall resulting in expansion of the cell wall. These changes most likely affect the degree of available hydroxyl groups due to changes in molecular structure of cell wall. The water molecules form a monolayer of water molecules on the surface of cell wall by hydrogen bonds with the available hydroxyl groups at low relative humidity (monomolecular adsorption-Stage I). However, there are still many sorption sites for water vapour adsorption which are blocked due to the complex arrangement of cellulose, hemicellulose and lignin matrix as visualized in Fig. 13a. For relative humidity between 30 and 50\%, the water vapour molecules build up a multilayer (Multilayer adsorption-II) and some blocked hydroxyl groups are available to water vapour molecules due to the change in molecular structure of the cell wall. Multilayer adsorption continues above RH 50\%, but water sorption by capillary condensation becomes dominant. The pore size distribution of the specimens is associated to the beginning of capillary condensation. Finally, there is a small portion of blocked 
sorption sites further opened to the water vapour molecules above RH 50\%.

\section{Conclusions}

It is the first time to compare the moisture and heat sorption characteristics of hemp shiv, hemp fibre, flax shiv and flax fibre based on their physical and chemical properties. Although the shiv and fibre for both flax and hemp had difference in microstructure, porosity and portion of chemical composition, all specimens had a similar moisture adsorption content at a particular relative humidity. This was dependent on the available hydroxyl groups for water molecules in the specimens, which was more or less independent of the macroscopic surface area and porosity of the specimen at large scale $(>50 \mathrm{~nm})$. The isotherm hysteresis of the shiv were much higher than that of the fibre in the range of $9-90 \%$ relative humidity. The extent of hysteresis exhibited was dependent on the content of lignin. As a result, for the first time the woody hemp shiv has been reported to have a differentsorption isotherm between the first and subsequent sorption cycles. The enthalpy of heat sorption was stronger for the initial layer of water molecules and then progressively decreased over successive layers. The total enthalpy change across the full range of humidity was greater than the heat of vaporisation of liquid water. This indicated that some blocked sorption sites become available to water vapour molecules due to the change in molecular structure of the cell wall during the adsorption process. This work offers a developed understanding of the moisture sorption mechanism for bio-based plant materials.

Acknowledgments The work presented here was carried out under the ISOBIO project, with funding from the European Union's Horizon 2020 research and innovation programme, under Grant agreement No. 636835.

Conflicts of interest We declare we have no competing interests.

Open Access This article is distributed under the terms of the Creative Commons Attribution 4.0 International License (http:// creativecommons.org/licenses/by/4.0/), which permits unrestricted use, distribution, and reproduction in any medium, provided you give appropriate credit to the original author(s) and the source, provide a link to the Creative Commons license, and indicate if changes were made.

\section{References}

Berthold J, Desbrières J, Rinaudo M, Salmén L (1994) Types of adsorbed water in relation to the ionic groups and their counter-ions for some cellulose derivatives. Polymer 35(26):5729-5736

Berthold J, Olsson RJO, Salmén L (1998) Water sorption to hydroxyl and carboxylic acid groups in carboxymethylcellulose (CMC) studied with NIR-spectroscopy. Cellulose 5(4):281-298

Bledzhi AK, Gassan J (1999) Composites reinforced with cellulose based finbres. Prog Polym Sci 24(2):221-274

Bouguerra A, Sallée H, de Barquin F, Dheilly RM, Quéneudec M (1999) Isothermal moisture properties of wood-cementitious composites. Cem Concr Res 29(3):339-347

Bourdot A, Moussa T, Gacoin A, Maalouf C, Vazquez P, Thomachot-Schneider C, Bliard C, Merabtine A, Lachi M, Douzane O, Karaky H, Polidori G (2017) Characterization of a hemp-based agro-material: influence of starch ratio and hemp shive size on physical, mechanical, and hygrothermal properties. Energy Build 153(Supplement C):501-512

Boutin M-P, Flamin C, Quinton S, Gosse G (2005) Analyse du cycle de vie de mur en béton chanvre banché sur ossature en bois (life cycle analysis of a cast hemp-lime timberframed wall). INRA, Lille

Brunauer S, Emmett PH, Teller E (1938) Adsorption of gases in multimolecular layers. J Am Chem Soc 60(2):309-319

Célino A, Fréour S, Jacquemin F, Casari P (2013) The hygroscopic behavior of plant fibers: a review. Front Chem 1:43

Collet F, Pretot S (2014) Thermal conductivity of hemp concretes: variation with formulation, density and water content. Constr Build Mater 65(Supplement C):612-619

Collet F, Bart M, Serres L, Miriel J (2008) Porous structure and water vapour sorption of hemp-based materials. Constr Build Mater 22(6):1271-1280

Collet F, Achchaq F, Djellab K, Marmoret L, Beji H (2011) Water vapor properties of two hemp wools manufactured with different treatments. Constr Build Mater 25(2):1079-1085

Collet F, Chamoin J, Pretot S, Lanos C (2013) Comparison of the hygric behaviour of three hemp concretes. Energy Build 62(Supplement C):294-303

Collet F, Prétot S, Lanos C (2017) Hemp-straw composites: thermal and hygric performances. Energy Procedia 139:294-300

Ehrnrooth RML (1984) Change in pulp fibre density with acid chlorite delignification. J Wood Chem Technol 4:91-109

Engelund Emil T, Thygesen Lisbeth G, Hoffmeyer P (2010) Water sorption in wood and modified wood at high values of relative humidity. Part 2: appendix. Theoretical assessment of the amount of capillary water in wood microvoids. Holzforschung 64:325

Engelund ET, Thygesen LG, Svensson S, Hill CAS (2013) A critical discussion of the physics of wood-water interactions. Wood Sci Technol 47(1):141-161

Esteves B, Velez Marques A, Domingos I, Pereira H (2013) Chemical changes of heat treated pine and eucalypt wood monitored by FTIR. Maderas Ciencia y tecnología $15: 245-258$ 
Ferreira PDS, Stefanowski B, Maskell D, Ormondroyd G, Ansell M, Dengel A, Ball R (2017) Improvement of indoor air quality by MDF panels containing walnut shells. Build Environ 123:427-436

Garcia C, Jaldon D Dupeyre, Vignon MR (1998) Fibres from semi-retted hemp bundles by steam explosion treatment. Biomass Bioenerg 14(3):251-260

Hill CAS, Norton A, Newman G (2009) The water vapor sorption behavior of natural fibers. J Appl Polym Sci 112(3):1524-1537

Hill CAS, Norton AJ, Newman G (2010) The water vapour sorption properties of Sitka spruce determined using a dynamic vapour sorption apparatus. Wood Sci Technol 44(3):497-514

Hill CAS, Ramsay J, Keating B, Laine K, Rautkari L, Hughes M, Constant B (2012) The water vapour sorption properties of thermally modified and densified wood. J Mater Sci 47(7):3191-3197

His I, Andème-Onzighi C, Morvan C, Driouich A (2001) Microscopic studies on mature flax fibers embedded in LR White: immunogold localization of cell wall matrix polysaccharides. J Histochem Cytochem 49(12):1525-1535

Hurtado PL, Rouilly A, Vandenbossche V, Raynaud C (2016) A review on the properties of cellulose fibre insulation. Build Environ 96(Supplement C):170-177

Jiang Y, Lawrence M, Ansell MP, Hussain A (2018) Cell wall microstructure, pore size distribution and absolute density of hemp shiv. R Soc Open Sci 5(4): 171945

Kollmann F (1962) Eine gleichung der sorptionsisotherme. Sci Nat 49(9):206-207

Kostic M, Pejic B, Skundric P (2008) Quality of chemically modified hemp fibers. Biores Technol 99(1):94-99

Kymäläinen H-R, Sjöberg A-M (2008) Flax and hemp fibres as raw materials for thermal insulations. Build Environ 43(7):1261-1269

Laborel-Préneron A, Aubert JE, Magniont C, Tribout C, Bertron A (2016) Plant aggregates and fibers in earth construction materials: a review. Constr Build Mater 111(Supplement C):719-734

Latif E, Tucker S, Ciupala MA, Wijeyesekera DC, Newport D (2014) Hygric properties of hemp bio-insulations with differing compositions. Constr Build Mater 66:702-711

Latif E, Ciupala MA, Tucker S, Wijeyesekera DC, Newport DJ (2015) Hygrothermal performance of wood-hemp insulation in timber frame wall panels with and without a vapour barrier. Build Environ 92(Supplement C):122-134

Mauze GR, Stern SA (1984) The dual-mode solution of vinyl chloride monomer in poly(vinyl chloride). J Membr Sci 18:99-109

Mikhalovska LI, Gun'ko VM, Rugal AA, Oranska OI, Gornikov YI, Morvan C, Follain N, Domas C, Pakhlov EM, Mikhalovsky SV (2012) Cottonised flax fibres vs. cotton fibres: structural, textural and adsorption characteristics. RSC Adv 2(5):2032-2042

Mokhothu TH, John MJ (2015) Review on hygroscopic aging of cellulose fibres and their biocomposites. Carbohyd Polym 131:337-354
Nakamura K, Hatakeyama T, Hatakeyama H (1981) Studies on bound water of cellulose by differential scanning calorimetry. Text Res J 51(9):607-613

Nilsson D, Svennerstedt B, Wretfors C (2005) Adsorption equilibrium moisture contents of flax straw, hemp stalks and reed canary grass. Biosyst Eng 91(1):35-43

Pandey KK (1999) A study of chemical structure of soft and hardwood and wood polymers by FTIR spectroscopy. J Appl Polym Sci 71(12):1969-1975

Picandet V (2017) Bulk density and compressibility. In: Amziane S, Collet F Bio-aggregates based building materials: State-of-the-art report of the RILEM technical committee 236-BBM. Springer, Dordrecht, pp 111-124

Popescu C-M, Hill CAS (2013) The water vapour adsorptiondesorption behaviour of naturally aged Tilia cordata Mill. wood. Polym Degrad Stab 98(9):1804-1813

Rahim M, Douzane O, Le Tran AD, Promis G, Laidoudi B, Crigny A, Dupre B, Langlet T (2015) Characterization of flax lime and hemp lime concretes: hygric properties and moisture buffer capacity. Energy Build 88:91-99

Rana R, Langenfeld-Heyser R, Finkeldey R, Polle A (2010) FTIR spectroscopy, chemical and histochemical characterisation of wood and lignin of five tropical timber wood species of the family of dipterocarpaceae. Wood Sci Technol 44(2):225-242

Ross K, Mazza G (2010) Characteristics of lignin from flax shives as affected by extraction conditions. Int J Mol Sci 11:4035-4050

Siau JF (1984) Transport processes in wood. Springer, Berlin

Skaar C (1984) Wood-water relationships. Chem Solid Wood Am Chem Soc 207:127-172

Stefanidis SD, Kalogiannis KG, Iliopoulou EF, Michailof CM, Pilavachi PA, Lappas AA (2014) A study of lignocellulosic biomass pyrolysis via the pyrolysis of cellulose, hemicellulose and lignin. J Anal Appl Pyrol 105:143-150

Thommes M, Kaneko K, Neimark AV, Olivier JP, RodriguezReinoso F, Rouquerol J, Sing SWK (2015) Physisorption of gases, with special reference to the evaluation of surface area and pore size distribution (IUPAC technical report). Pure Appl Chem 87:1051

Thygesen A, Daniel G, Lilholt H, Thomsen AB (2006) Hemp fiber microstructure and use of fungal defibration to Obtain fibers for composite materials. J Nat Fibers 2(4):19-37

Viel M, Collet F, Lanos C (2018) Chemical and multi-physical characterization of agro-resources by-product as a possible raw building material. Ind Crops Prod 120:214-237

Vignon MR, Garcia-Daldon C, Dupeyre D (1995) Steam explosion of woody hemp chenevotte. Int J Biol Macromol 17:395-440

Vrentas JS, Vrentas CM (1991) Sorption in glassy polymers. Macromolecules 24(9):2404-2412

Walker R, Pavía S (2014) Moisture transfer and thermal properties of hemp-lime concretes. Constr Build Mater 64:270-276

Wang S, Javadpour F, Feng Q (2016) Confinement correction to mercury intrusion capillary pressure of shale nanopores. Sci Rep 6:20160 